
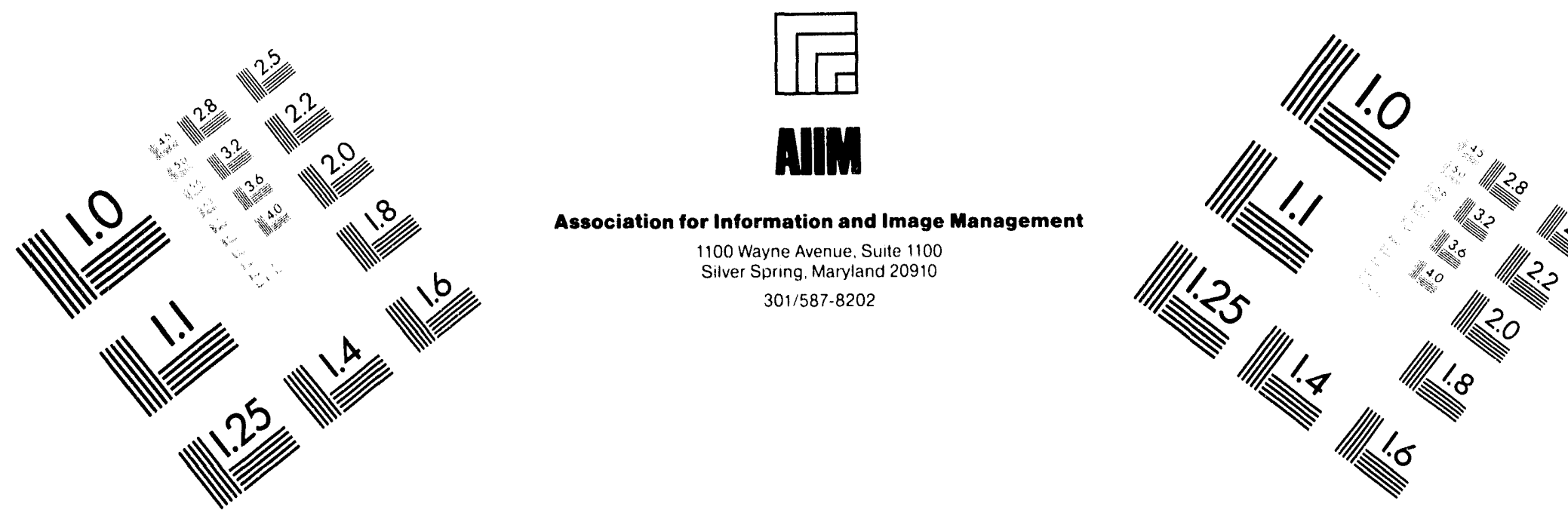

\title{
Centimeter
}

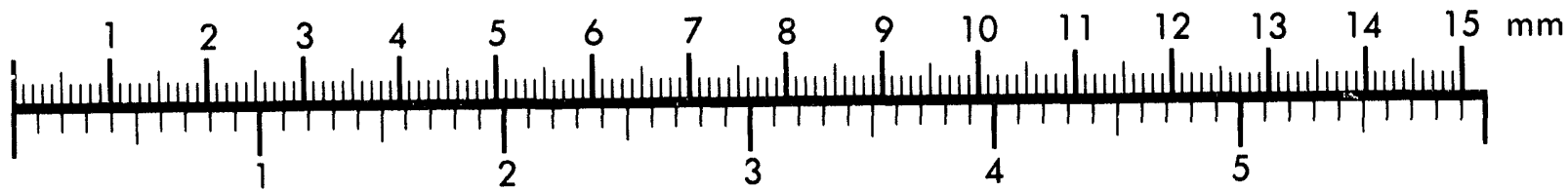
Inches
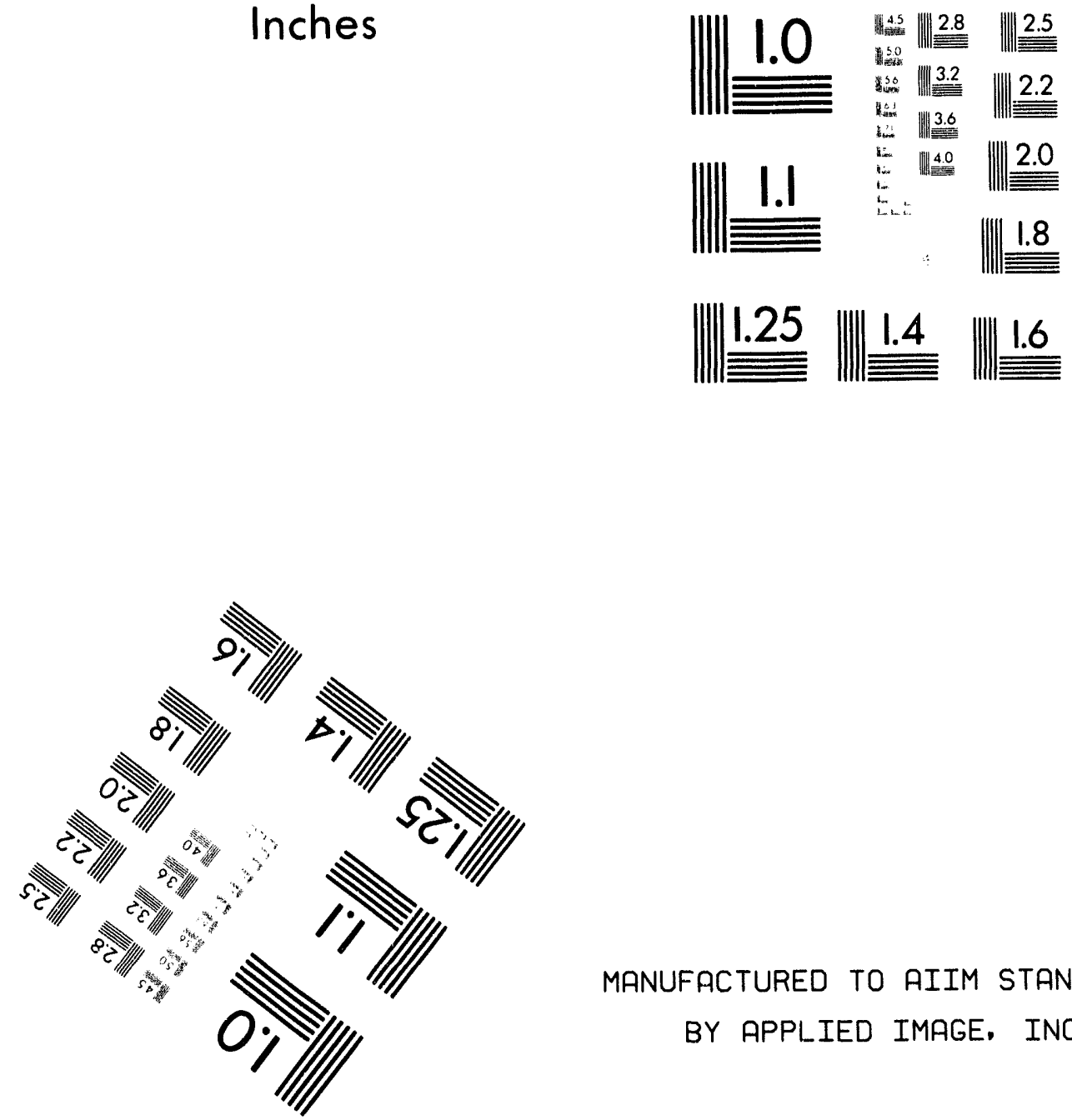

MANUFACTURED TO AIIM STANDARDS

BY APPLIED IMAGE, INC.

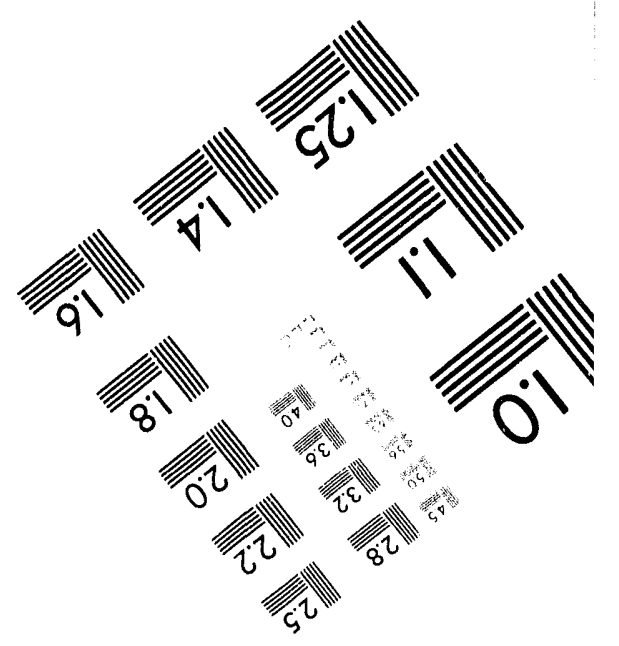



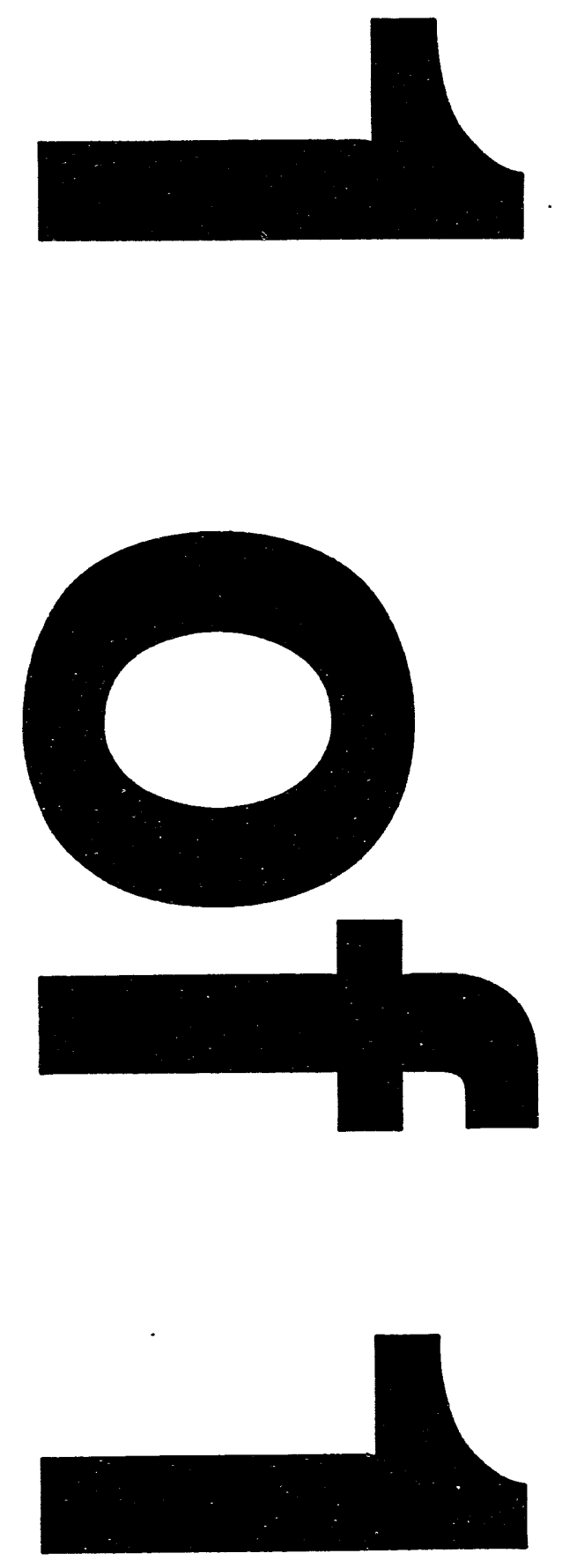


\section{Experimental Logistics Plan} in Support of Extensive

Separations for Hanford Tank Waste Remediation Systems

W. I. Enderlin

J. L. Swanson

C. D. Carlson

E. J. Hirschi

December 1993

Prepared for the U.S. Department of Energy under Contract DE-AC06-76RLO 1830

Pacific Northwest Laboratory

Operated for the U.S. Department of Energy

by Battelle Memorial Institute 


\title{
DISCLAIMER
}

This report was prepared as an account of work sponsored by an agency of the United States Government. Neither the United States Government nor any agency thereof, nor Battelle Memorial Institute, nor any of their employees, makes any warranty, expressed or implied, or assumes any legal liability or responsibility for the accuracy, completeness, or usefulness of any information, apparatus, product, or process disclosed, or represents that its use would not infringe privately owned rights. Reference herein to any specific commercial product, process, or service by trade name, trademark, manufacturer, or otherwise does not necessarily constitute or imply its endorsement, recommendation, or favoring by the United States Government or any agency thereof, or Battelle Memorial Institute. The views and opinions of authors expressed herein do not necessarily state or reflect those of the United States Government or any agency thereof.

\author{
PACIFIC NORTHWEST LABORATORY \\ operated by \\ BATTELLE MEMORIAL INSTITUTE \\ for the \\ UNITED STATES DEPARTMENT OF ENERGY \\ under Contract DE-ACO6-76RLO 1830
}

Printed in the United States of America

Available to DOE and DOE contractors from the

Office of Scientific and Technical Information, P.O. Box 62, Oak Ridge, TN 37831.

prices available from (615) 576-8401. FTS 626-8401.

Avallable to the public from the National Technical Information Service,

U.S. Department of Commerce, 5285 Port Royal Rd., Springfield, VA 22161. 
Experimental Logistics Plan in Support of Extensive Separations for Hanford Tank Waste Remediation Systems

\author{
W. I. Enderlin \\ J. L. Swanson \\ C. D. Carlson \\ E. J. Hirschi
}

December 1993

Prepared for

the U.S. Department of Energy under Contract DE-AC06-76RLO 1830

Pacific Northwest Laboratory Richland, Washington 99352 


\section{Executive Summary}

The Extensive Separations Development Program was conducted during 1992 and 1993 to complement the U.S. Department of Energy (DOE) and contractor strategies for treatment of defense wastes by identifying chemical separation processes that if implemented would 1) minimize the volume of high-level wastes to be disposed of in a geologic repository and 2) reduce the activity, toxicity, and quantity of low-level wastes to be stored in onsite, near-surface repositories.

Development of the technologies and data needed to support deployment decisions on various features of an extensive separations approach to treatment of Hanford tank wastes would require extensive experimentation. This is largely because there is considerable variability in the chemical composition and physical characteristics of the wastes and, as a result, these materials are complex and difficult to separate. It is envisioned that experiments would be conducted at Pacific Northwest Laboratory (PNL) and/or at other DOE laboratories to determine the behavior of multiple varieties of tank waste supernate, saltcake, and sludge during a broad range of processing.

As part of this effort, PNL has developed a logistics plan that identifies the key logistical/resource requirements that would be necessary for this experimentation effort. This plan addresses the following logistics aspects of the experimentation program: waste material and experimental processing requirements, sample acquisition, sample transport, and final disposition of residual sample material. The plan takes a total systems view of the experimental process and identifies potential schedule impacts and available resources at Hanford and at other selected DOE laboratories. Also included is a time-phase estimate of the waste material requirements. Technical requirements necessary for implementation of the proposed experimentation program are also identified.

Two critical impacts to the logistics schedule are identified in this plan. One critical impact is the development of an appropriate Type B containment/transportation cask. Until such a cask is available, all actual tank waste experiments must be conducted at Hanford. Possible remedies that may be considered are

- provide a suitable shipping cask onsite, at Hanford, by December 6, 1993

- dedicate existing laboratory facilities and laboratory staff in the 325 Building at Hanford, or equivalent, to support this activity until a suitable shipping cask is provided.

A second critical impact involves waste sample retrieval. The logistic plan calls for cores to be taken up to three times per month, while current capabilities demonstrate that only one to two samples per month can be retrieved. If samples are not retrieved according to the proposed logistic schedule, an impact of 12 to 18 months should be anticipated. 


\section{Acknowledgments}

The authors are grateful to Dr. J. L. Straalsund (PNL) for his guidance and review of this work. The authors also wish to acknowledge the following named people for their contribution to this work:

\begin{tabular}{|c|c|c|c|}
\hline$\underline{W} S^{(a)}$ & Name & Organization & Area of Contribution \\
\hline 1 & Moses Attrep & LANL & Experimentation \\
\hline 2 & Bob Villarreal & LANL & Experimentation \\
\hline 2 & Jim Ledbetter & LANL & Hot Cell Logistics \\
\hline 2 & Larry Field & LANL & Hot Cell Logistics \\
\hline 2 & Glenn Bently & LANL & Transportation/Receiving/Storage \\
\hline \multirow[t]{2}{*}{2} & George Vandegrift & ANL & Experimentation/Logistic Issues \\
\hline & Joe Hoh & ANL & Hot Cell Logistics \\
\hline 2 & Emory Collins & ORNL & Experimentation/Logistic Issues \\
\hline 2 & Zane Egan & ORNL & Experimentation/Logistic Issues \\
\hline 2 & Mark Mc Alaster & SNL & Container Development \\
\hline 2 & Richard Yoshimura & SNL & Container Development \\
\hline 2 & Anthony Trennel & SNL & Experiment \\
\hline 2 & Pat Young & WHC & Sample Retrieve/Package/Transport \\
\hline 2 & Jim Eide & WHC & Sample Transportation \\
\hline 1 & Julian Hill & WHC & Waste Characterization \\
\hline \multirow[t]{2}{*}{1,2} & Richard Karnesky & WHC & Sample Groupings/Logistic Issues \\
\hline & Tom Oden & WHC & Sample Planning \& Prioritization \\
\hline 1 & Steven A. Barker & WHC & Experimentation \\
\hline 2 & Joel Tingey & PNL & Hot Cell Logistic Issues \\
\hline 2 & Francis Buck & PNL & Logistics Issues/Requirements \\
\hline \multirow[t]{2}{*}{1} & Gregg J. Lumetta & PNL & Experimentation \\
\hline & C. R. Allen & PNL & Hot Cell Availability \\
\hline 1,2 & Tom Wood & PNL & Data Quality Objectives \\
\hline 1,2 & Major C. Thompson & SRTC & Experimentation \\
\hline
\end{tabular}

(a) WS Indicates workshop participation:

1 = Experimental Needs

2 = Experimental Logistics Requirements. 


\section{Definitions}

Core segment

Core

Core composite

Waste type

Waste type composite

Test

Step

Process

Flowsheet

Raffinate waste contained in one 19-in.-long by 1.125-in.-diameter core sampler sum of core segments from one drilling operation

weighted mix of portions of homogenized core segments from one core "meaningful" grouping of tanks believed to contain chemically similar waste

a weighted mix of portions of core composites from a single waste type

an experiment

an "extraction" operation (i.e., TRU removal)

candidate method for a step (i.e., TRUEX)

combination of processes for a portion of the clean option (i.e., PUREX + TRUEX + SREX + CsIX)

solvent-lean, residual feed solution with one or more constituents removed by extraction 


\section{Contents}

Executive Summary $\ldots \ldots \ldots \ldots \ldots \ldots \ldots \ldots \ldots \ldots \ldots \ldots \ldots \ldots \ldots$

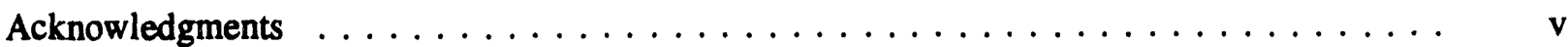

Definitions $\ldots \ldots \ldots \ldots \ldots \ldots \ldots \ldots \ldots \ldots \ldots \ldots \ldots \ldots \ldots \ldots \ldots \ldots$ vii

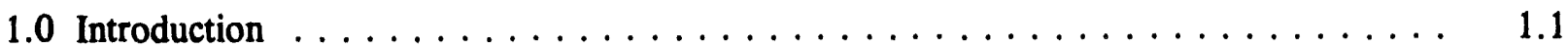

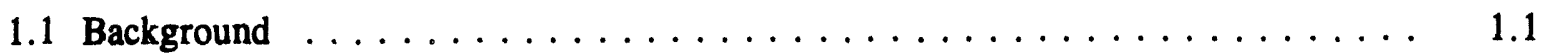

1.2 Report Organization $\ldots \ldots \ldots \ldots \ldots \ldots \ldots \ldots \ldots \ldots \ldots \ldots$

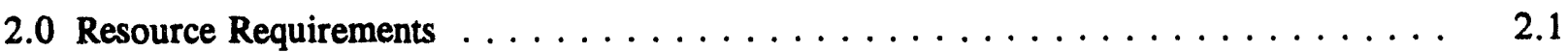

2.1 Assumptions Underlying Discussions of Extensive Separation Research $\ldots \ldots \ldots$

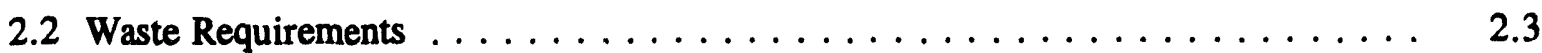

2.2.1 Total Waste Type Number Requirements . . . . . . . . . . . . . 2.3

2.2.2 Sludge Process Testing Requirements . . . . . . . . . . . . . . 2.3

2.2.3 Saltcake/Supernate Process Testing Requirements . . . . . . . . . . . . 2.4

2.2.4 Summary of Sample Requirements $\ldots \ldots \ldots \ldots \ldots \ldots$

2.3 Laboratory Facility Requirements $\ldots \ldots \ldots \ldots \ldots \ldots \ldots \ldots$

2.4 Long-Term Requirements . . . . . . . . . . . . . . . . . . . . . . . 2.10

2.5 Sample Acquisition and Preparation Requirements . . . . . . . . . . 2.10

2.6 Packaging and Transportation Requirements $\ldots \ldots \ldots \ldots \ldots \ldots \ldots \ldots$

2.7 Waste Material Disposition Requirements $\ldots \ldots \ldots \ldots \ldots \ldots \ldots \ldots \ldots$

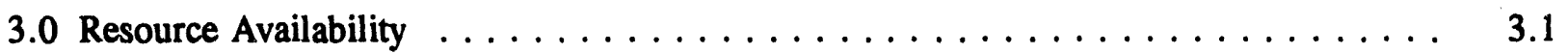

3.1 Hanford Resources $\ldots \ldots \ldots \ldots \ldots \ldots \ldots \ldots \ldots \ldots \ldots$

3.1.1 Sample Acquisition $\ldots \ldots \ldots \ldots \ldots \ldots \ldots \ldots \ldots \ldots \ldots \ldots$

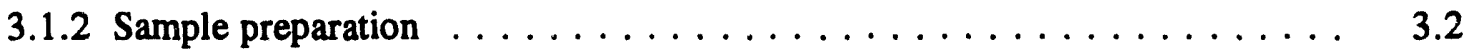


3.1.3 Sample Packaging and Transport . . . . . . . . . . . . 3.2

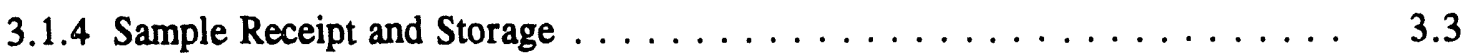

3.1 .5 Hot Cell Availability $\ldots \ldots \ldots \ldots \ldots \ldots \ldots \ldots \ldots \ldots$

3.1.6 Waste Material Disposition $\ldots \ldots \ldots \ldots \ldots \ldots \ldots \ldots \ldots$

3.1 .7 Analytical Support $\ldots \ldots \ldots \ldots \ldots \ldots \ldots \ldots \ldots \ldots \ldots$

3.2 Oak Ridge National Laboratory Resources $\ldots \ldots \ldots \ldots \ldots \ldots \ldots$

3.2.1 Hot Cell Availability $\ldots \ldots \ldots \ldots \ldots \ldots \ldots \ldots \ldots \ldots \ldots \ldots$

3.2.2 Waste Material Disposition $\ldots \ldots \ldots \ldots \ldots \ldots \ldots \ldots$

3.2 .3 Analytical Support $\ldots \ldots \ldots \ldots \ldots \ldots \ldots \ldots \ldots \ldots$

3.3 Argonne National Laboratory Resources $\ldots \ldots \ldots \ldots \ldots \ldots$

3.3.1 Hot Cell Availability $\ldots \ldots \ldots \ldots \ldots \ldots \ldots \ldots \ldots \ldots$

3.3.2 Waste Material Disposition $\ldots \ldots \ldots \ldots \ldots \ldots \ldots \ldots \ldots$

3.3.3 Analytical Support $\ldots \ldots \ldots \ldots \ldots \ldots \ldots \ldots \ldots \ldots \ldots$

3.4 Savannah River Technology Center Resources $\ldots \ldots \ldots \ldots \ldots$

3.4.1 Hot Cell Availability $\ldots \ldots \ldots \ldots \ldots \ldots \ldots \ldots \ldots \ldots \ldots$

3.4.2 Waste Material Disposition $\ldots \ldots \ldots \ldots \ldots \ldots \ldots \ldots \ldots \ldots$

3.4 .3 Analytical Support $\ldots \ldots \ldots \ldots \ldots \ldots \ldots \ldots \ldots \ldots$

3.5 Los Alamos National Laboratory Resources . . . . . . . . . . . . . . 3.9

3.5.1 Hot Cell Availability $\ldots \ldots \ldots \ldots \ldots \ldots \ldots \ldots \ldots \ldots$

3.5.2 Waste Material Disposition $\ldots \ldots \ldots \ldots \ldots \ldots \ldots \ldots$

3.5.3 Analytical Support . . . . . . . . . . . . . . . . . 3.9

3.6 Sandia National Laboratory Resources $\ldots \ldots \ldots \ldots \ldots \ldots$

3.6.1 Hot Cell Availability $\ldots \ldots \ldots \ldots \ldots \ldots \ldots \ldots \ldots \ldots \ldots$

3.6.2 Waste Material Disposition $\ldots \ldots \ldots \ldots \ldots \ldots \ldots \ldots \ldots \ldots \ldots$ 
3.6 .3 Analytical Support $\ldots \ldots \ldots \ldots \ldots \ldots \ldots \ldots \ldots \ldots \ldots \ldots \ldots$

4.0 Technical Requirements $\ldots \ldots \ldots \ldots \ldots \ldots \ldots \ldots \ldots \ldots \ldots \ldots \ldots \ldots$

5.0 Schedule and Critical Path Impacts $\ldots \ldots \ldots \ldots \ldots \ldots \ldots \ldots \ldots \ldots \ldots$

5.1 Sample Retrieval Schedule Considerations $\ldots \ldots \ldots \ldots \ldots \ldots \ldots \ldots \ldots$

5.2 Packaging and Transportation Schedule Considerations $\ldots \ldots \ldots \ldots \ldots \ldots$

5.2 .1 Schedule Information $\ldots \ldots \ldots \ldots \ldots \ldots \ldots \ldots \ldots \ldots \ldots$

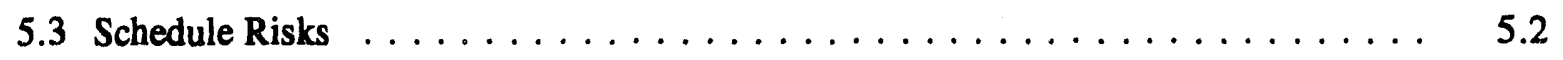

5.4 Schedule Summary $\ldots \ldots \ldots \ldots \ldots \ldots \ldots \ldots \ldots \ldots \ldots \ldots$

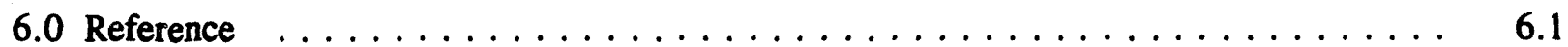




\section{Figures}

2.1 Distribution Diagram 1: Initial Sludge Testing, 100 Cores $\ldots \ldots \ldots \ldots \ldots$

2.2 Distribution Diagram 2: Scaled-Up Sludge Testing and Contingency,

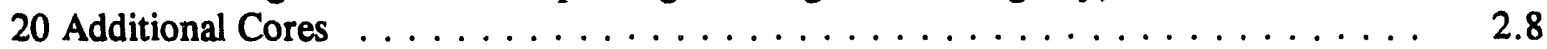

2.3 Distribution Diagram 3: Saltcake/Supernate Testing, No Additional Cores $\ldots \ldots \ldots . .2 .9$

5.1 Experimental Logistics $\ldots \ldots \ldots \ldots \ldots \ldots \ldots \ldots \ldots \ldots \ldots \ldots \ldots \ldots$

\section{Tables}

2.1 Process Steps in Extensive Separations Experimentation $\ldots \ldots \ldots \ldots \ldots \ldots \ldots$

2.2 Tank Waste Samples Needed to Reach Go/No-Go Decision Within 5 Years . . . . . . 2.6

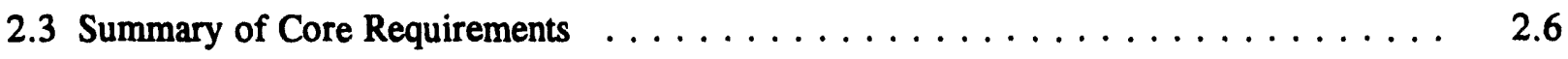




\subsection{Introduction}

All proposed methods for remediating the radioactive and chemical waste stored in single- and double-shell tanks (SSTs and DSTs) at the Hanford Site require the separation of the waste mixtures in the tank into high-level and low-level fractions, the safe transport of this separated waste to appropriate immobilization facilities, and the long-term disposal of the immobilized waste forms. Extensive experimentation, especially in waste separations, will be required to develop the technologies and to produce the data that support the most effective and safe cleanup processes.

As part of this effort, Pacific Northwest Laboratory (PNL) $)^{(a)}$ is developing this detailed experimental logistics plan to determine the logistical/resource requirements, and ultimately the critical paths, necessary to effectively and safely conduct the multitude of experiments within the Extensive Separations Development Program, which addresses the experimental needs of a concept that provides a high degree of separation for the high-level and low-level waste fractions. The logistics issues developed for this program are expected to be similar to those for other programs aimed at remediating and disposing of the wastes.

\subsection{Background}

The overall mission of Extensive Separations is to complement the U.S. Department of Energy (DOE) and contractor strategies for long-term disposal of defense wastes by developing and implementing chemical separation processes that 1) reduce high-level wastes to a volume consistent with available geologic repository space and 2) reduce the activity, toxicity, and quantity of residual wastes to levels acceptable for storage in onsite, near-surface repositories.

The purpose of Extensive Separations is to develop and deploy chemical processing technology to 1) separate the Hanford tank wastes into high-level and low-level fractions suitable for disposal in, respectively, geologic and near-surface repositories and 2) minimize the quantities of all types of wastes that require long-term storage.

A successful Extensive Separations program will reduce the amount of high-level waste to a volume that can be accommodated in the planned geologic repository, will decrease the activity and toxicity of most of the Hanford tank wastes to a level that would permit their permanent disposal on the Hanford Site as low-level solid waste, and will substantially reduce the overall quantity of low-level waste thereby reducing storage costs and risks.

(a) The Pacific Northwest Laboratory is operated for the U.S. Department of Energy by Battelle Memorial Institute under Contract DE-AC06-76RLO 1830. 
Before the validity of the Extensive Separations concept can be determined, an experimental program involving (but not limited to) actual wastes must be conducted. It should be noted that this testing is not unique to the Extensive Separations concept; no pretreatment or treatment concept should be selected for deployment without such testing. Of the potential pretreatment concepts considered to date, the Extensive Separations concept will probably require the most experimental evaluation. A 5-year period for testing this and other concepts has been assumed before one concept is chosen for implementation and a go/no-go decision is made.

To provide a basis for developing this experimental logistics plan, two workshops were held during fiscal year (FY) 1993 in Richland, Washington. The participants were from PNL, Los Alamos National Laboratory (LANL), Westinghouse Hanford Company (WHC), the Savannah River Technology Center (SRTC), Argonne National Laboratory (ANL), Sandia National Laboratory (SNL), and Oak Ridge National Laboratory (ORNL).

The main objective of Workshop 1 was to estimate the number and size of tank waste samples that would be required for the experiments during the first 5 years, which would lead to a technically sound go/no-go decision. The emphasis was on SSTs, although the DSTs were also considered, if appropriate. A secondary objective included estimating available staff, facilities, and equipment requirements leading to the go/no-go decision and resource requirements after the 5-year study. The participants were from PNL, WHC, SRTC, and LANL.

To develop estimates of the requirements needed for the experiments, the participants addressed issues such as

- the size of sample needed to test process chemistry for each meaningful waste type

- the minimum number of waste types into which the tank wastes can meaningfully be grouped from a process-chemistry perspective

- the number of samples for each meaningful waste type that would be needed for testing

- the time-phased sample requirements over the assumed 5-year period leading to the go/no-go decision.

The decision regarding future development of the Extensive Separations Program would be based on several key experimental measurements with the numerous types of wastes. The key measurements would address the feasibility (and practicality) of performing the separations needed to achieve the program goals. It is important to determine if the tank waste sludges can be dissolved completely enough that the undissolved residues can be accommodated by the objective of 1000 canisters of high-level waste (HLW) or, alternatively, if the undissolved residues can be leached free of radionuclides so they can be sent to low-level waste (LLW) rather than to HLW. If neither of these approaches can be done under practical process conditions, then one of the primary goals of Extensive Separations Program 
cannot be achieved. Similarly, certain difficult separations (e.g., trivalent lanthanides from trivalent actinides and barium from strontium) must be performed under practical process conditions for the program goals to be achieved. These major areas of uncertainty are in addition to the primary process steps of efficiently "extracting" the important radionuclides (e.g., transuranic elements [TRUs], ${ }^{137} \mathrm{Cs}$, ${ }^{90} \mathrm{Sr},{ }^{9} \mathrm{Tc}$ ) from the major bulk components (e.g., sodium, aluminum, iron, etc.) so the radionuclides can be sent to HLW and the bulk components can be sent to LLW; these primary extraction steps must

also be tested with real wastes. In addition, all of these processes must not add significantly to the total volumes of the waste fractions.

If the experimental results are positive, sufficient tank samples should have been tested within the indicated 5-year period that a technically sound "go" decision regarding further development and eventual implementation of an Extensive Separations Program can be made. However, negative results within the 5-year test period could result in a "no-go" decision.

Workshop 2 focused on identifying the experimental logistics requirements required to support the waste material and experimental processing needs identified in Workshop 1. Information developed as a result of Workshop 1, together with information gathered as a result of reviewing pertinent documents and contacting cognizant staff, provided the foundation for Workshop 2. The participants were from PNL, LANL, WHC, SRTC, SNL, ANL, and ORNL and included staff with experience pertaining to key logistics issues.

\subsection{Report Organization}

This logistics plan takes a total systems view of the experimental process and identifies schedule impacts on the critical path. The plan includes a time-phased estimate of the waste material requirements derived from the programmatic objectives and a schedule for the Extensive Separations Development Program.

The document is organized to answer the following questions:

- What requirements are necessary to research the waste separations problem? (Section 2.0)

- What resources are currently available? (Section 3.0)

- Based on the technical requirements, are the current resources adequate? (Section 4.0)

- What will it take to conduct the experiments in the prescribed 5-year period? (Section 5.0)

Section 5.0, which discusses impacts to the schedule, builds on previous sections to present information that is central to the Extensive Separation planning effort. 


\subsection{Resource Requirements}

The following sections discuss the assumptions used by workshop participants and the resources required to conduct the experimental program.

\subsection{Assumptions Underlying Discussions of Extensive Separations Research}

The following assumptions were used by the workshop participants to reduce the constraints on the process and allow the development of requirements for performing the necessary research:

1. There are no budgetary constraints either for sampling or research.

2. Laboratory availability is not an issue; this includes the capability of handling the wastes at various sites.

3. It was assumed that samples will be shipped to both Hanford and other DOE laboratories.

4. Development will occur on more than one process per step.

5. Manpower will be available in all phases of the project.

6. Core sampling capacity will not be a limiting factor. The current core sampling estimates were taken into account, but the workshop participants assumed that this experimentation effort would be assigned top priority in the availability of material from the core samples. Experimental needs would dictate which tanks are to be sampled to meet these needs.

7. Fifty waste types will provide adequate variability in the tank sludge samples (this rationale will be discussed later in this report).

8. Preliminary testing will show that a reduced number of waste types (three) will be acceptable for scaled-up testing to provide for a go/no-go decision.

9. Simulants will be acceptable for the preliminary testing of the saltcake/supernate processes.

10. The work leading to a go/no-go decision must be completed within 5 years, by the beginning of FY 1999.

11. It is assumed that the process steps reflected in Table 2.1 are representative of the Extensive Separations concept (Straalsund et al. 1992) and that real waste will be required for the process steps where indicated in Table 2.1. 
Table 2.1. Process Steps in Extensive Separations Experimentation

\begin{tabular}{ll}
\multicolumn{1}{c}{ Process Step } & Is Real Waste \\
\cline { 2 - 2 } Saltcake dissolution & yes \\
Sludge wash & yes \\
Sludge dissolution/leach & yes \\
Nitrate destruction & yes(a) \\
Organic destruction & yes \\
TRU "extraction" \\
Acid side & \\
Basic side & yes \\
Strontium "extraction" & yes \\
Acid side \\
Basic side & \\
Cesium "extraction" & yes \\
Acid side & yes \\
Basic side & \\
Technetium "extraction" & yes \\
Acid side & yes \\
Basic side & \\
Iodine "extraction" & yes \\
Acid side & yes \\
Basic side & yes \\
Am/Ln separation & \\
Sr/Ba separation & no \\
TRU/Bi separation & no \\
Ni "extraction" & no \\
Solid/liquid separation & no \\
& yes
\end{tabular}

(a) A substantial portion of the work in this area can be validly performed using waste simulants.

These working assumptions were used to facilitate the progress of Workshop 1, and many of the assumptions are of questionable validity. For example, in assumptions 1 and 6 (no constraints on funding or sampling capacity), it is almost certain that constraints will be greater than assumed, but these working assumptions allowed the program needs to be more fully defined. Knowledge of these needs will then allow the real-life constraints to be identified and evaluated, which was the purpose of this study. 


\subsection{Waste Requirements}

\subsubsection{Total Waste Type Number Requirements}

In the case of sludge waste forms, there is a great deal of variability in the composition of the waste. Moreover, the workshop participants concluded that the number of tank waste types is not well known; however, current best estimates indicate approximately 47 types of SST waste and 6 types of DST waste. Consequently, the participants agreed that using approximately 50 types of waste for sludge dissolution testing would give a wide enough range of tank wastes to encompass the extremes of behavior (with respect to the Extensive Separations processing schemes) and allow for a reasonably sound go/no-go decision regarding implementation of the Extensive Separations concept. Because the saltcake/supernate matrix is much less complex than the matrix for sludges, it was concluded by Workshop 1 participants that three saltcake/supernate waste types samples would adequately describe the conditions present in all of the waste tanks. One type would contain relatively high sodium concentration, a second type would contain relatively low sodium concentration, and a third type would contain organic complexants, such as the complexant concentrate waste.

Because direct information on the components in the waste tanks is not available, tracking of radioactive components (TRAC) analysis and the sorts on radioactive waste types (SORWT) analysis will be used to make inventory estimations. The TRAC analysis is a computer model designed to estimate the overall inventories of radionuclides in the Hanford underground storage tanks (USTs). While this system was not designed to give tank-by-tank estimates of the inventories, it is currently the best process available for estimating the inventories in the individual tanks. The SORWT analysis is a report based on the operational history of the Site and is only available in draft form; an update has been planned but is not yet available. The most up-to-date data available will be used in conjunction with the TRAC analysis to determine which tanks need to be sampled.

\subsubsection{Sludge Process Testing Requirements}

The process requirements for the sludge testing will be much greater than those for the saltcake/ supernate processing due to the more complex nature of the matrix. Whereas the dissolved saltcake/ supernate is a solution with the major ionic components consisting of sodium salts, the sludge will have a wide range of solubility properties and consist of widely varying chemical compositions. The testing of the pretreatment options for the sludge will be performed in three major steps: 1) dissolution/leach testing, 2) post-dissolution testing, and 3) scaled-up testing. The dissolution testing should be started early in FY 1994, the post-dissolution testing beginning by July 1994, and the scaled-up tests commencing by July 1997.

\section{Dissolution/Leach Testing}

The dissolution/leach tests of all of the $\mathbf{5 0}$ waste types will determine the completeness of sludge dissolution, or alternatively, completeness of leaching of radionuclides. Sequenced dissolution/leach 
tests on approximately 1.0-g core samples from two of the Hanford SSTs have already been performed at PNL. Based on these test results, Workshop 1 participants estimated that $2 \mathrm{~g}$ of core composite sludge per test, 3 tests per core composite, 2 core composites per waste type, and 50 waste types for the experimentation are required. Hence, a total of $600 \mathrm{~g}$ of material $(12 \mathrm{~g}$ from each of the waste types) is required. For planning purposes, it was assumed that the work would be divided among three sites.

\section{Post-dissolution Testing}

The next test sequence, post-dissolution testing, will involve the batch testing of dissolved waste solutions in the various processes that are candidates for the removal of the radionuclides. Each step of a candidate flowsheet was assumed to have three processes worthy of study. Testing of each process was assumed to require $20 \mathrm{~g}$ of core composite sludge. This scope of testing would require $300 \mathrm{~g}$ of samples each from the 50 waste type composites, or $15 \mathrm{~kg}$ total: (3 processes/step) x (5 steps) x ( $20 \mathrm{~g} /$ sample/process) $\times$ (50 waste type composites) $=15 \mathrm{~kg}$. For planning purposes, it was assumed that the testing would be performed by five different investigators.

\section{Scaled-up Testing}

The next test sequence would be a scaled-up testing of two candidate flowsheets, selected based on the results of the preceding work. This activity will involve bench-scale testing of the various processes with a limited number of wastes. It is assumed that three waste types would be chosen to represent the range of sludge samples in the Hanford underground storage tanks. It is estimated that $12 \mathrm{~kg}$ of material (4 $\mathrm{kg}$ per waste type) would be required to perform the scaled-up testing on the sludge wastes. For planning purposes, it is assumed that the two flowsheets would be tested at different sites. It is also assumed that these tests would be bench-scale solvent extraction tests that would be run using $2-\mathrm{cm}$ centrifugal contactors. Such contactors will allow steady state to be achieved with $0.5 \mathrm{~L}$ of feed for 20 stages and $1.5 \mathrm{~L}$ of feed for 60 stages. Since the samples will be processed through the whole flowsheet, the raffinate from one step will be the feed for the next step. Based on the results obtained from dissolution studies at PNL, Workshop 1 participants estimated that $0.3 \mathrm{~L}$ of sludge will be required to prepare $1.5 \mathrm{~L}$ of feed. A volume of $0.3 \mathrm{~L}$ of sludge will weigh $0.45 \mathrm{~kg}$; however, to be conservative, it is estimated that $0.65 \mathrm{~kg}$ of sludge will be required for each test. The amount of sludge needed for continuous testing will be $4 \mathrm{~kg}$ per waste type, or $12 \mathrm{~kg}$ total: $(0.65 \mathrm{~kg} /$ test $) \times$ (three tests/waste type/flowsheet) $\times$ (two flowsheets) $=4 \mathrm{~kg}$.

\subsubsection{Saltcake/Supernate Process Testing Requirements}

As stated in the assumptions, the bulk of the testing of the alkaline-side extractions will be performed on waste simulants. Three candidate flowsheets, which will have been identified from the simulant testing, will be tested with the actual wastes. The simulant testing should be completed and the 
candidate flowsheets chosen by the beginning of FY 1996, at which time the batch testing on the actual tank wastes will begin, followed by the scaled-up testing. The first of the waste samples will have to be delivered by October 1, 1995.

\section{Initial Testing with Actual Wastes}

It is estimated that initial testing of three candidate flowsheets with actual saltcake/supernate will require approximately $8 \mathrm{~kg}$ of samples. This estimate is based on $0.1 \mathrm{~kg}$ per test, three tests per composite by each of three investigators, and three composites of each of three waste types. For planning purposes, it is assumed that the work would be performed at three different sites.

This waste quantity estimate is assumed to be valid even though the individual values used to arrive at the final value may be changed. The $0.1-\mathrm{kg}$ test value is based on the use of ion exchange columns having approximately $2-\mathrm{mL}$ bed volumes. Although there may be up to six different steps involved in a flowsheet, the same sample can often be used to test multiple steps.

\section{Scaled-Up Testing}

It is estimated that the scaled-up testing of two candidate flowsheets would require approximately $42 \mathrm{~kg}$ of saltcake/supernate. This is based on six tests at $7 \mathrm{~kg}$ per test. The $7-\mathrm{kg}$ value assumes that $7 \mathrm{~kg}$ of saltcake/supernate will give $20 \mathrm{~L}$ of feed solution and that the tests will use $100-\mathrm{mL}$ ion exchange columns and 200 column volumes of feed. For planning purposes, it is assumed that the work will be performed at two different sites.

\subsubsection{Summary of Sample Requirements}

The testing requirements discussed in Sections 2.2.2 and 2.2.3 are summarized in Table 2.2. This table shows the quantities needed for the different types of testing and also gives the time-phased sample requirements for the samples that will be required to come to a go/no-go decision. The amounts of waste presented in this table are current best estimates and will likely be modified as more information becomes available.

Table 2.3 summarizes the core requirements. In preparing this table, it was assumed that an average core will consist of an average of seven segments, with $300 \mathrm{~g}$ of sample per segment. Of this $2100 \mathrm{~g}, 1050 \mathrm{~g}$ will be sludge and $1050 \mathrm{~g}$ will be saltcake/supernate. There is also an assumption that $30 \%$ of each core will not be usable because of losses during transfer and homogenization, leaving only $735 \mathrm{~g}$ of each category available for experimental use. The distribution of sample material among the various tests is depicted in Figures 2.1, 2.2, and 2.3. 
Table 2.2. Tank Waste Samples Needed to Reach Go/No-Go Decision Within 5 Years

Waste types

Composites/type

Required wt. (g)

- total

- per investigator

- per composite

- for 1 test

Date of need

- first sample

- last sample

\begin{tabular}{c} 
Dissolution/leach \\
Tests \\
\hline 50 \\
2
\end{tabular}

600

200

6

2

$10 / 1 / 93$
$7 / 1 / 96$
Sludge

Post-dissolution

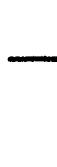

Tests
$\begin{gathered}50 \\ 1\end{gathered} \frac{\text { Tests }}{3}$
1

15,000

3,000

300

20

$7 / 1 / 94$
$1 / 1 / 97$
12,000

6,000

4,000

650

$7 / 1 / 97$

7/1/98

\begin{tabular}{rr}
\multicolumn{2}{c}{ Saltcake/supernate } \\
\hline $\begin{aligned} \text { Initial } \\
\text { Tests }\end{aligned}$ & $\begin{array}{c}\text { Scaled-up } \\
\text { Tests }\end{array}$ \\
\cline { 1 - 1 } 3 & 1 \\
3 & 3
\end{tabular}

8,100

42,000

2,700

21,000

2,700

14,000

100

7,000

$10 / 1 / 95$

4/1/97

$1 / 1 / 97$

Table 2.3. Summary of Core Requirements

\begin{tabular}{|c|c|c|c|}
\hline & $\begin{array}{c}\text { Number of Cores } \\
\text { Required }\end{array}$ & $\begin{array}{c}\text { Required Core } \\
\text { Sampling Schedule }\end{array}$ & $\begin{array}{c}\text { Amount of Sample per } \\
\text { Core }\end{array}$ \\
\hline $\begin{array}{l}\text { Dissolution/leach } \\
\text { testing of sludges }\end{array}$ & $\begin{array}{l}100 \text { cores from } \\
10 / 1 / 93 \text { to } 4 / 1 / 96\end{array}$ & $\begin{array}{l}10 \text { cores every } 3 \\
\text { months }\end{array}$ & $6 \mathrm{~g}$ \\
\hline $\begin{array}{l}\text { Post-dissolution testing } \\
\text { of sludges }\end{array}$ & $-(a)$ & & $150 \mathrm{~g}$ \\
\hline $\begin{array}{l}\text { Scaled-up testing of } \\
\text { sludges }\end{array}$ & $\begin{array}{l}20 \text { cores from } \\
4 / 1 / 96 \text { to } 4 / 1 / 98^{(b)}\end{array}$ & $\begin{array}{l}5 \text { cores every } 6 \\
\text { months }\end{array}$ & $735 \mathrm{~g}$ \\
\hline $\begin{array}{l}\text { Initial testing of actual } \\
\text { saltcake/supernate }\end{array}$ & $-(0)$ & & \\
\hline $\begin{array}{l}\text { Scaled-up testing of } \\
\text { saltcake/supernate }\end{array}$ & $--^{(d)}$ & & \\
\hline
\end{tabular}

(a) All of the samples required can be obtained from the cores collected for the dissolution testing.

(b) In addition to the $\mathbf{2 0}$ cores collected for this testing, the remainder of the appropriate sludge types from the cores collected for dissolution and post-dissolution testing will be used to perform the scaled-up testing.

(c) All of the material required can be obtained from the saltcake/supernate portion of the cores collected for the dissolution/leach testing.

(d) All of the material required can be obtained from the saltcake/supernate portion of the cores collected for the dissolution/leach and scaled-up sludge testing. 


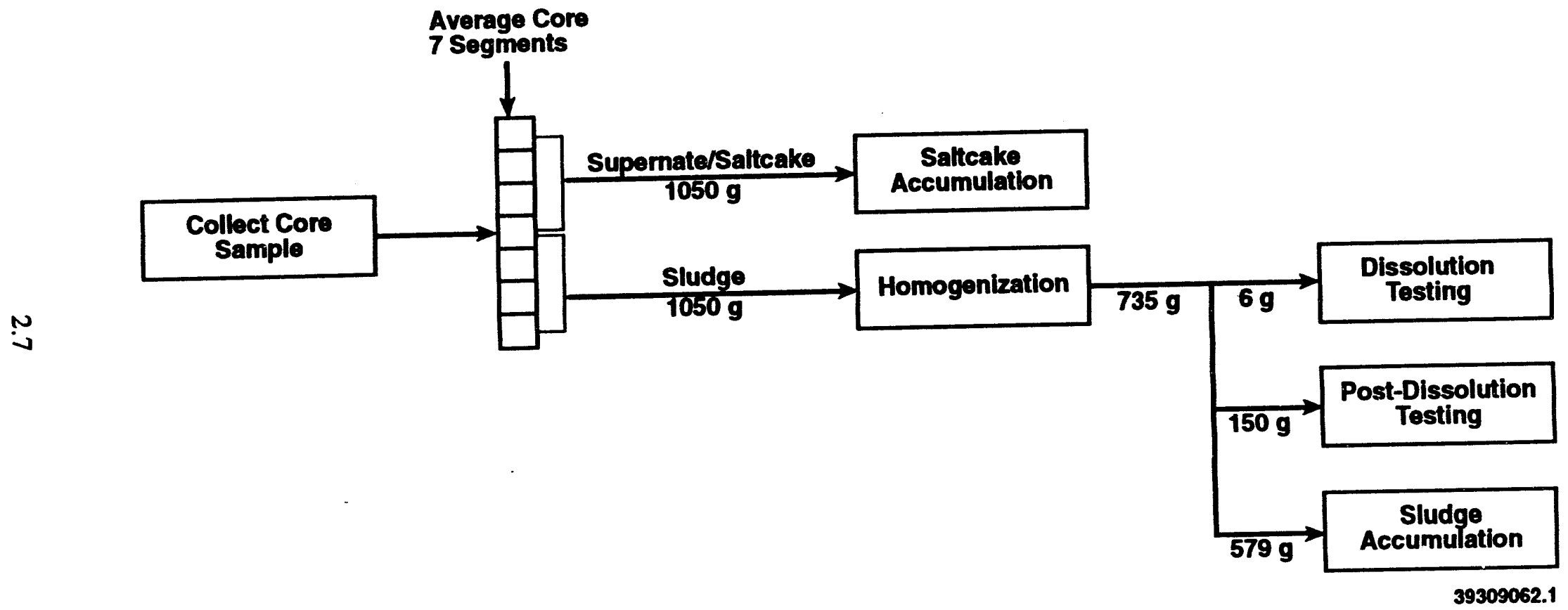

Figure 2.1. Distribution Diagram 1: Initial Sludge Testing, 100 Cores (50 Waste Types) 


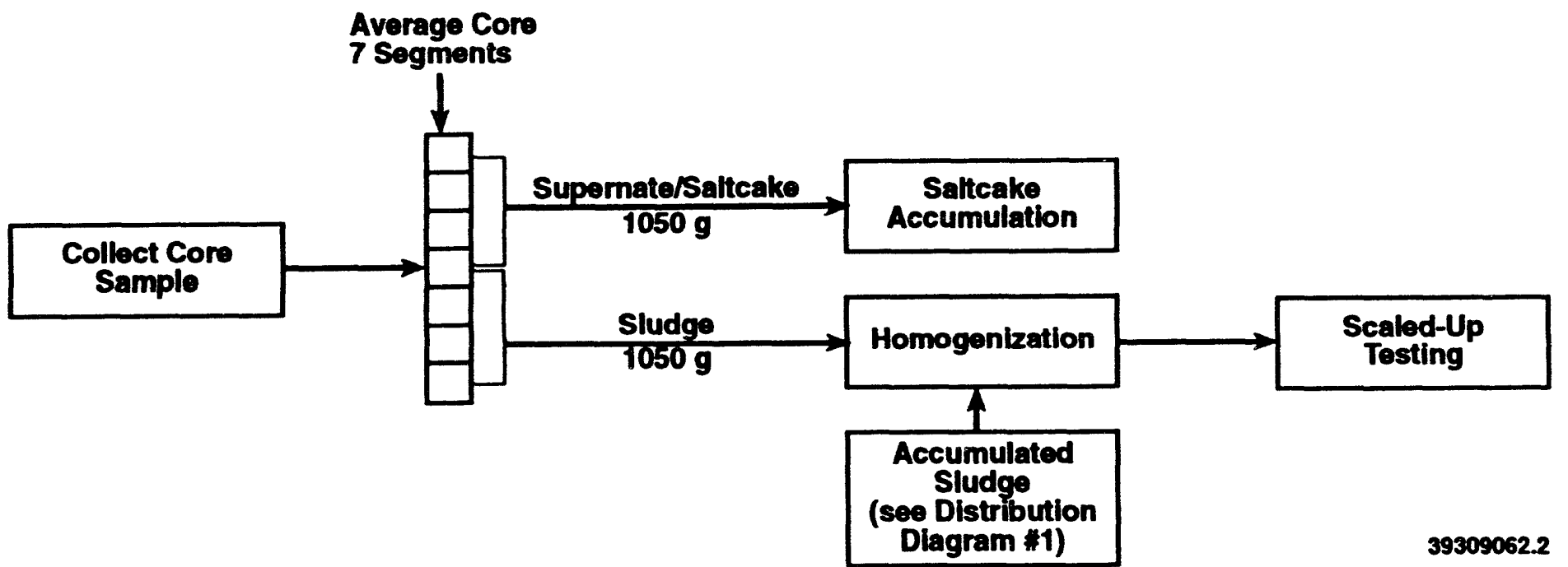

Figure 2.2. Distribution Diagram 2: Scaled-Up Sludge Testing and Contingency, 20 Additional Cores ( $\bar{x}$ three waste types) 


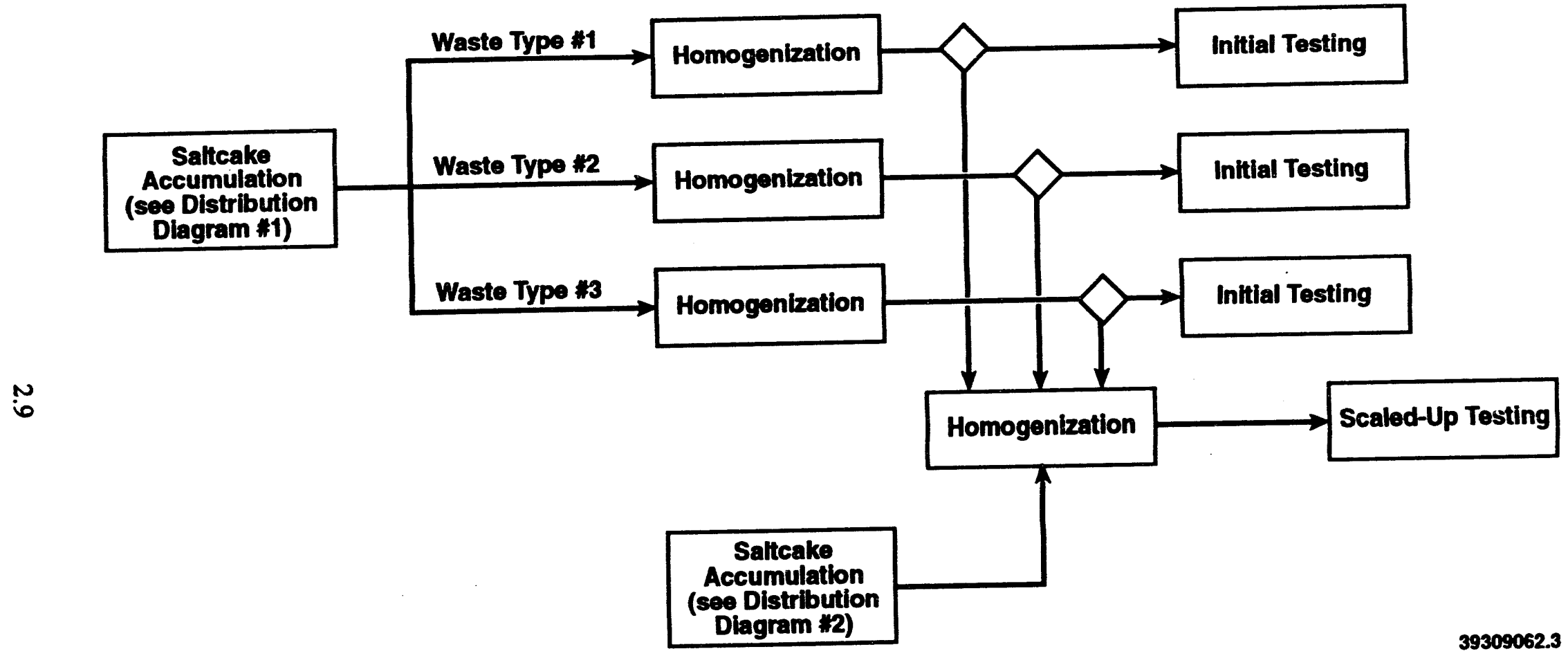

Figure 2.3. Distribution Diagram 3: Saltcake/Supernate Testing, No Additional Cores (three waste types) 


\subsection{Laboratory Facility Requirements}

The preliminary dissolution studies can be performed in a hood. The exposure limits for work in laboratories at PNL is $10,000 \mathrm{mrem} / \mathrm{h}$. To date, all of the Hanford SST wastes that PNL has studied have had a low enough dose rate that the hoods have provided adequate protection. If a small amount of shielding is required, a glovebox should suffice for such samples. If an extremely hot sample is encountered, a hot cell may be required, but it would have to be a small hot cell (e.g., the 325-A or 325-B hot cells in the 325 Building at PNL) with Model-8 master-slave manipulators or equivalent.

The same conditions would exist for the post-dissolution tests. The majority of the work could be performed in hoods or gloveboxes, with the possibility of requiring a small hot cell with delicate manipulators.

For the scaled-up testing, a hot cell will be required. The dose rates will be such that direct manipulation of the experiments will be impossible. To perform a continuous countercurrent run using 40 stages, the minimum floor space requirements were estimated to be $116 \mathrm{ft}^{2}$. This will accommodate two 20-stage banks of centrifugal contactors and the peripheral equipment such as storage tanks. The banks of contactors are about $1.5 \mathrm{ft}$ in diameter by $2 \mathrm{ft}$ long and weigh approximately $250 \mathrm{lb}$.

\subsection{Long-Term Requirements}

Previous discussions have dealt with the investigations that will be necessary in the 5-year period leading to a point when a go/no-go decision can be made regarding the Extensive Separations concept. In addition, if the decision is to proceed with development, some thought must be given to requirements after the 5-year study period. If the planning is not in place, there would be delays in the delivery of samples to perform the out-year testing and development. One set of tests that would need to be performed in the out-years would be long-term testing of the processes for both saltcake/supernate and sludge to determine the effects of factors such as contaminant buildup in the processes. This testing would require several additional $100-\mathrm{kg}$ samples and would require larger hot cells than were required for scaled-up testing.

\subsection{Sample Acquisition and Preparation Requirements}

Before tank waste sample material can be made available to support the experimentation, it is required that the experimentation needs reflected in Tables 2.2 and 2.3 first be integrated into the master core sampling schedule (MCSS) for TWRS. The core sampling and sample preparation activities are on the critical path for this project. The MCSS reflected in WHC-SD-WM-T1-532, Revision 0 , is reportedly no longer considered by TWRS to be valid. A pretreatment core sampling priority list, which was agreed upon by representatives of the PNL experimental logistics planning team and the 
WHC Pretreatment Program Planning Office, was provided by WHC Pretreatment Program Planning to the office that maintains the MCSS. A revised MCSS incorporating this information is currently scheduled to be released by September 30, 1993.

Adequate core-sampling capacity is required to accommodate the additional sample quantities, types, and need dates that are reflected in Tables 2.2 and 2.3. The previously mentioned pretreatment core sampling priority list assumes that two sampling trucks are available to take 10 to 15 cores per truck per year, depending on sampling mode. It also assumes that two additional sampling trucks will be available in FY 1997 and FY 1998.

Adequate hot cell and laboratory capacity and sufficient numbers of qualified staff are required for extruding and homogenizing the sample and for performing the chemical analysis to support the sample homogenization activity in a timely manner. Hot cell space will also be needed to perform the scaledup testing, both at Hanford and at any potential offsite location(s). In addition, it is required that a sufficient portion of the overall homogenized sample from selected tanks be available for supporting the experimentation. The quantities of sample required are identified in Table 2.2.

Adequate interim storage is required to accommodate the sample material and mixed waste associated with providing homogenized sample material to the Extensive Separations experimentation activity.

\subsection{Packaging and Transportation Requirements}

Shipping containers are required for transporting rotary mode or push mode samplers containing core sample material from the tank farm to the laboratories in the $\mathbf{3 0 0}$ Area at Hanford. It is not a requirement that these packages be Department of Transportation (DOT) certified as long as they are transported within the Hanford Site under road closure conditions; however, the packages must satisfy DOT requirements. A minimum of 12 containers should be available to provide three containers for each of the two sample trucks with a back-up set of three casks for each truck in the cask turn-around process at all times.

It is planned that shipping packages will also be required to ship sample material offsite to other DOE laboratories for the purpose of performing portions of the needed work at those locations. It is required that the package have sufficient capacity to accommodate the quantities of homogenized sample material specified in Table 2.2 or that multiple shipments be made with smaller packages, providing that sufficient sample holding capacity is available at the sample destination. It is required that these containers be compatible with the cask handling capability at the 222-S and 325-A Facilities at Hanford and with the cask-handling capability at the potential destination facilities (ANL, LANL, ORNL, SRTC, SNL). 
It is anticipated that the concentrations of ${ }^{90} \mathrm{Sr},{ }^{137} \mathrm{Cs}$, and ${ }^{241} \mathrm{Am}$ will exceed the allowable $\mathrm{A}_{1}$ and $A_{2}$ values for these radionuclides for Type A containers, as listed in 49 CFR 173.433. Moreover, it is anticipated that the homogenized sample material will be recognized as a liquid, because it will probably exhibit readiness to flow. Consequently, the packages that will be used to ship homogenized core sample material offsite will most likely have to be certified as Type B packages for liquid, in accordance with 10 CFR 71.

The exact number of Type B shipping containers that will be required depends on 1) the required frequency of shipment, which, in turn, is a function of sample availability and/or sample need; 2) the number of composites to be shipped; 3 ) the quantity of each composite required; 3 ) the capacity of the shipping container; 4) the number of destinations and their relative distance from Hanford; and 5) the time required for turn-around of the container at the destination and to ship it back to Hanford.

Because all of these factors are not known at this time, the exact number of Type B containers required is indeterminate. However, based on the need dates reflected in Table 2.2 and assuming the involvement of at least four offsite laboratories, it is estimated that a minimum of four such containers would be required.

\subsection{Waste Material Disposition Requirements}

There is a requirement to dispose of waste material generated as a result of acquiring a sample, homogenizing a sample, and performing the experimental tests. It is required that the sample tool and drill string used for retrieving each segment be packaged and stored at Hanford as radioactive mixed waste. Also, approximately $30 \%$ of each segment is lost to waste during the homogenization process and must be discarded at Hanford as radioactive mixed waste. Hanford is the only facility currently capable of homogenizing core sample material containing saltcake. Most of the material used in experimentation must also be disposed of as radioactive mixed waste. To comply with this requirement, residue sample material from experimentation performed offsite may or may not be returned to Hanford for disposal as radioactive mixed waste, depending on the quantity of material involved and the waste disposal options at a specific offsite facility. The volume of waste that must be disposed of increases directly as the demand for sample material increases. 


\subsection{Resource Availability}

The resource availability information presented in this section is organized by DOE site.

\subsection{Hanford Resources}

\subsubsection{Sample Acquisition}

Currently, obtaining sufficient samples from some tanks for Extensive Separations experimentation is uncertain. The Defense Nuclear Facilities Safety Board (DNFSB) currently advocates a plan whereby 7 to 10 targeted analytes would be analyzed within 45 days of obtaining a sample, and all of the residue core material would be held in storage for further analysis at a later date, in compliance with the Tri-Party Agreement. A revised tank sampling plan is currently being developed that reflects these other priorities for sampling; however, it is likely that the material in some of these tanks will not satisfy the experimental needs of this project. According to this plan, two cores per tank would not be available for experimentation; hence, the experimental need identified in Section 2.0 would not be satisfied.

The following operational parameters dictate the rate at which a sample can be acquired:

- The sampling process requires an average of 9 days to extract one core from a tank. There are, on an average, seven segments in a core; however, core length ranges from 2 to 20 segments.

- Of the two trucks available for transporting sample material, only one is used between the Wye Barricade and the laboratories in the 300 Area to reduce egress from contaminated areas. This truck carries a maximum of three sample casks per trip, each cask containing one sampler/segment (a total of $300 \mathrm{cc}$ to $900 \mathrm{cc}$ of sample material per trip and from one to seven round trips per core).

The following operational constraints impede sample material acquisition and distribution:

- For rotary mode, the exhauster system is currently designed to be operated when the temperature of the tank vapor space is above $60^{\circ} \mathrm{F}$.

- Tank containment cannot be broken when it is raining.

- Tank containment cannot be broken when wind speed exceeds $15 \mathrm{mph}$, unless a weather barrier is in place. Currently, weather barriers are not employed because their installation is considered to be too expensive. 
- The location of obstructions (e.g., berms, equipment enclosures, risers in use, etc.) in the vicinity of some tanks inhibit the placement of equipment required for acquiring a sample, resulting in significantly increased setup time.

- Sample recovery is poor (often less than 50\%) in the case of push-mode operation. Recovery is anticipated to be much greater in rotary-mode operation.

- Gas-generating tanks must be monitored and evaluated for a minimum of 3 months prior to acquiring a sample.

\subsubsection{Sample preparation}

It is currently planned that two facilities at Hanford capable of extruding core sample and of homogenizing sample material containing saltcake will be in operation by June 1984. These will be located in the 222-S Building and at the 325-A Facility. Currently, both facilities have push-mode extrusion capability, but only the 325-A Facility is equipped to extrude and homogenize core samples containing saltcake. The capability for sample extrusion and homogenization is not known to exist at any other DOE facility.

It requires approximately 30 days to process a sample/segment through the $325-\mathrm{A}$ Facility. This includes unloading the cask, removing the sampler from the cask, extruding the sample, homogenizing the sample, performing chemical analysis to verify adequate homogenization, and packaging the sample for shipment. The chemical analysis activity accounts for most of the 30-day period. At present, this facility can homogenize five segments per day containing sludge and/or supernate (to date, no core sample containing saltcake has been homogenized in this facility). During normal sampling operations using the push mode, the laboratory has received an average of one core per month; however, more could be handled. In the past, core delivery has often not kept up with laboratory processing.

\subsubsection{Sample Packaging and Transport}

The casks that transport samplers from the tank farm to the laboratories in the Hanford 300 Area for extrusion and homogenization are not DOT-approved; hence, cask transport is confined to off-shift hours under road closure conditions. There appears to be a sufficient quantity of these containers to accommodate a tank sampling schedule that incorporates Extensive Separations experimentation requirements. There has, however, been an occasion when a sample has had too high a dose to transport via these casks. PNL has a facility for decontaminating, refurbishing, and inspecting these units in preparation for returning them to the field.

There are DOT-approved Type B casks that are available for transporting milliliter quantities of waste material. However, DOT-approved Type B casks are currently not available of sufficient size for transporting homogenized waste sample material from Hanford to other DOE laboratories in the quantities and of the types required to support Extensive Separations experimentation. A 5-g sample of 
Hanford tank waste from tank T-111, core 31 , segment 7 , measuring $13 \mathrm{mR} / \mathrm{h}$, was shipped to LANL using a 125-mL sample-pig and sample-pig shipping container. Reportedly, there are two or three containers of this type at Hanford.

At Workshop 2, SNL staff stated that it is reasonable to assume that a DOT-approved Type B casks of less than 1000-L capacity will be available within 2 years to support Extensive Separations experimentation. SNL is currently been asked by DOE/EM-36 to explore the feasibility of developing such a package. Options currently being considered by SNL are 1) modification of an existing package with a capacity of less than $10 \mathrm{~L}$, requiring a modification to the Certificate of Compliance for change of content; 2) modification of an existing package to attain a capacity of greater than $10 \mathrm{~L}$ but less than $1000 \mathrm{~L}$, requiring a modification to the Certificate of Compliance for change of form and contents; and 3) implementation of a new package, requiring design, testing, and SRP submittal to DOE/EH-33 or the U.S. Nuclear Regulatory Commission (NRC). Options 1 or 2 would support initial experimentation activities. It is currently unknown if option 3 would support Extensive Separations experimentation because the time required to receive a Certificate of Compliance is not set.

A package (MFP) has been designed by LANL for shipment of solid or liquid samples of radioactive material consisting of drill back samples of residue withdrawn from the cavity formed by a nuclear device test at the Nevada Test Site. The package has a cavity volume of 333.26 in. $^{3}(5.46 \mathrm{~L})$ and is intended to be classified as a Type $B(U)$. It is planned that six units will be delivered by midSeptember 1993. One unit is scheduled for performance testing in mid-October 1993 to meet Type A requirements. The additional units would be available for Type B certification efforts. Currently, funding for such an effort is not anticipated by LANL. If Type B certification can be obtained within a reasonable time frame, it may be possible that this package would also support the Extensive Separations experimentation effort, providing that the materials of construction and shielding are compatible with Hanford tank waste material.

In the case of a follow-on pilot plant operation, requiring large quantities of sample (several hundred kilograms), offsite shipment of sample material may not be a viable option in the near future, because of lack of an adequate shipping container.

\subsubsection{Sample Receipt and Storage}

PNL has a crane capacity up to 30 tons for handling shipping containers. In the 325-A High-Level Radiochemistry Facility, PNL also has satellite storage both inside hot cells and outside hot cells for storing sample material. In addition, a dry storage carrousel rated for $600,000 \mathrm{Ci}$ is located in the 327 Building. This facility can accommodate 810 cans that are 2.5 in. in diameter by 8 in. high (or two cans that are each 4 in. high). Currently, this facility contains less than $20 \%$ of its allowable storage capacity. However, if the DNFSB-preferred sampling plan is implemented, whereby residual core material is held for further testing, available storage space may become quite limited. 


\subsubsection{Hot Cell Availability}

Core extrusion and core sample homogenization to support the TWRS sludge characterization program are currently accomplished in B-Cell located in the 325-A High-Level Radiochemistry Facility at PNL. This cell is $6.5 \mathrm{ft}$ long by $8.3 \mathrm{ft}$ wide by $15 \mathrm{ft}$ high (54- $\mathrm{ft}^{2}$ floor area) and is equipped with through-the-wall remote manipulators. The cell is fully lined with stainless steel and is equipped with floor drains that drain into critically safe sump tanks in a shielded basement vault. The facility has a cask-handling capability of 30 tons. A cell in the 222-S Analytical Laboratory, operated by WHC, is also being provided with the capability for extruding core samples obtained by rotary mode and for homogenizing core sample material containing saltcake, for the purpose of supporting the TWRS sludge characterization program. Currently, these are the only identified facilities throughout the DOE complex set up to perform these activities.

It is anticipated, based on past PNL experience in analyzing tank waste, that the radiation exposure rate would be less than the 10,000 -mrem/h exposure limit in the case of most of the Extensive Separations dissolution/leach and post-dissolution tests; hence, these experiments would be performed in hoods in the 325 Building, resulting in a low dose rate. In the event that an extremely hot sample is encountered during the dissolution/leach or post-dissolution studies, A-cell or C-cell of the 325-A Facility or the hot cells in the 325-B Shielded Analytical Laboratory at PNL could be available to support this activity. The 325-B Facility contains six cells, each of which is $5.5 \mathrm{ft}$ long by $6 \mathrm{ft}$ wide by $6.25 \mathrm{ft}$ high ( $33 \mathrm{ft}^{2}$ floor area each), and equipped with Model-8 master-slave manipulators. Hot cells $\mathrm{C}, \mathrm{D}$, and $\mathrm{E}$ in the 327 Building would also be available to support this activity. These cells are $6 \mathrm{ft}$ by $4.3 \mathrm{ft}$ by $4.3 \mathrm{ft}\left(26 \mathrm{ft}^{2}\right.$ floor area each) and each cell is equipped with manipulators. Two shielded glove boxes and two hoods are available in the 324 Building, as well as a shielded glove box and numerous hoods in the 325 Building.

The cell that PNL would likely use for scaled-up testing is the $\mathrm{C}$ hot cell in the 324 Building. This cell is designed to be a multi-purpose cell for laboratory and engineering-scale radiochemical experimentation. Its dimensions are $12 \mathrm{ft}$ long by $19.3 \mathrm{ft}$ wide and $15 \mathrm{ft}$ high ( $231 \mathrm{ft}^{2}$ floor area), and it is lined with stainless steel. The cell is equipped with two pairs of Model-K master-slave manipulators and a 2-ton crane. The cell has an 18-by-18-in. door for sample transfer, but the equipment would be put into place through a 6-ft-wide by 8-ft-high door. This facility can accommodate up to a 30-ton cask. If required, this hot cell could be available for Extensive Separations experimentation within 1 to 2 years.

\subsubsection{Waste Material Disposition}

The 325-A High-Radiation-Level Storage Area for liquids consists of three underground vaults (A-, B-, and C-vaults). A-vault contains one 18,000-gallon stainless steel waste-storage tank and one 400-gallon transfer tank. B-vault contains two 3900-gallon stainless steel tanks. C-vault contains one 400-gallon and two 274-gallon stainless steel tanks. This facility would be available to receive waste generated as a result of core extrusion and sample homogenization. It would also be available to 
receive residue sample material returned from offsite facilities that had received sample material from Hanford for Extensive Separations experimentation and that were not able to dispose of the residual material onsite.

\subsubsection{Analytical Support}

The availability of the needed analytical support for Extensive Separations experimentation at Hanford is uncertain at this time. There is currently a problem with timely turnaround of analysis for process support due to the present priority status of the waste characterization program.

\subsection{Oak Ridge National Laboratory Resources}

\subsubsection{Hot Cell Availability}

One operational hot cell is currently available to support Extensive Separations experimentation. This would be cell B or D, located in Building 4501. The other three cells in this facility are currently supporting an ongoing program. The dimensions of these cells are $6 \mathrm{ft}$ long by $8 \mathrm{ft}$ wide by $15 \mathrm{ft}$ high. Both of these cells are equipped with a stainless steel liner, two lead glass windows with a Model CRL manipulator at each window, and a 10-ton bridge crane. Cell access consists of 34-by-17-in. doors at floor level, 36-by-36-in. doors in the upper cell wall, and ceiling plugs. Cask-handling capability is designed to introduce highly radioactive samples through the top of the cell from bottom loading casks. These hot cells would have ample floor space to perform dissolution/leach and post-dissolution tests, in the event an extremely hot sample is encountered. However, the floor space would not be sufficient for the scaled-up tests.

There are also four inactive hot cells in the 3047 Building and three hot cells in the 3029 Building. They are in good condition; however, funding would be required to return them to operation. These cells have a 25-ton cask-handling capability. The dimensions of these cells are not known nor if they are equipped with manipulators.

Approximately 16 hot cells are in the 3517 Building; however, the configuration, status, and availability are not completely known for all of them. Cells 1 through 4 have $1125 \mathrm{ft}^{2}$ of floor space and no viewing or manipulators. Cells 13 and 15 have windows, two Model E manipulators, and a 20-ton cask-handling capability. These cells may accommodate dissolution/leach and post-dissolution tests; however, they would not have sufficient floor space for scaled-up tests. Cell 14 has $160 \mathrm{ft}^{2}$ of floor area, three windows, five Model E manipulators, and a 20-ton cask-handling capability. Access is via a top plug (9.5 $\mathrm{ft} \times 7.5 \mathrm{ft})$. If available, this cell would be a candidate for scaled-up testing. 


\subsubsection{Waste Material Disposition}

The hot drains in each cell are administratively closed but would be available for emergency use. Liquid low-level waste is treated, bottled, and removed for disposal. According to the ORNL staff contacted, residual sample material could be disposed of at ORNL.

\subsubsection{Analytical Support}

ORNL analytical laboratory personnel have considerable experience in chemical analysis of mixed waste. Hoods and glove boxes are available; however, some analysis equipment would need to be purchased and set up for ORNL to perform all of the analyses required to support Extensive Separations experimentation. Moreover, the availability of the needed analytical support for Extensive Separations experimentation at ORNL is uncertain at this time due to the present priority status of the ongoing ORNL waste characterization program.

\subsection{Argonne National Laboratory Resources}

\subsubsection{Hot Cell Availability}

The ANL has several contactor test beds for solvent extraction experiments. The contactor test booth (H-125) allows for cold testing of one- or two-stage centrifugal contactors (contactors with rotor diameters from $10 \mathrm{~cm}$ through $25 \mathrm{~cm}$ or greater). The contractor test hood (A-109) facility allows for cold testing of solvent extraction processes, e.g., a TRUX flowsheet using laboratory-scale contactors. The contractor glove box (G-34) is used for the hot-testing of solvent extraction processes using laboratory-scale contactors. This facility is suitable for solutions high in alpha activity; however, it cannot be used when high levels of beta or gamma activity are present. If available, these facilities may be suitable for dissolution/leach and post-dissolution tests, as it is anticipated that the small quantities of Hanford tank waste involved will result in a low dose rate in most cases. The A-2 and A-3 hot cells in the M-Wing of the 200 Building are currently available, in the event a hot sample is encountered during the dissolution/leach or post-dissolution tests. Each hot cell has $49 \mathrm{ft}^{2}$ of floor area and is equipped with one window and two Model-8 manipulators. These hot cells are not equipped with a crane. Each hot cell is limited to $10 \mathrm{Ci}$.

The shielded-cell facility in the M-Wing of the 200 Building is a remote-operated facility that will support testing of solvent extraction processes using laboratory-scale contactors with very radioactive solutions. The K1, M1, and M3 hot cells in this facility would be suitable for Extensive Separations scaled-up tests, where the quantities of sample material required dictate the use of a hot cell. The M1 and M3 hot cells would be available to support this activity in about 2 years. The K1 hot cell would be available in about 1 year. The M1 and M3 hot cells each have $224 \mathrm{ft}^{2}$ of floor area, whereas the $\mathrm{K} 1$ hot cell has $252 \mathrm{ft}^{2}$ of floor area. Each of the three hot cells are equipped with four Model-8 and four Model-E manipulators, two windows, and a 1-ton bridge crane. The ceiling height in each cell is 
$12 \mathrm{ft}$; however, due to the manipulators, equipment placed into the cells cannot be higher than $10 \mathrm{ft}$. Access to each of these hot cells is via a 7-by-7-ft slab door or by an 8-by-12-ft transfer tunnel.

Shipping casks are received at the loading dock at the M-Wing of the 200 Building and then moved on a 20-ton lowboy to the front portion of the cave complex (on the service floor, lower level). Here, the shipping containers are remotely unloaded and the contents placed onto battery-driven radiocontrolled "mules" (small trucks running on a narrow gauge railway system that extends throughout the hot cell complex), servicing the K1 hot cell, located on the main floor, and the M1 and M3 hot cells, located on the service floor. Turntables are located at suitable locations to permit the "mules" to change direction of travel. An elevator at one end of the facility enables movement of the "mules" between floors.

The $C$ hot cell, located at the west end of "F" corridor in room K-104 of Building 205, is also currently sivailable to support Extensive Separations experimentation. This hot cell has a floor area of $67.5 \mathrm{ft}^{2}$ and is designed to handle $10 \mathrm{Ci}$ of $1-\mathrm{MeV}$ gamma activity. The cell is equipped with a manipulator, window, and bridge crane. This cell also has $10 \mathrm{ft}$ of useable height. Access is via a 4-by-4-ft by 6 -in.-thick door located at the rear of the cell, adjacent to the service area, which opens to the loading dock. Occasionally, it is necessary to access $\mathrm{A}$ and/or $\mathrm{B}$ hot cells via $\mathrm{C}$ hot cell; however, this disruption would not be frequent because the activity in A and B hot cells is of very long duration. This hot cell may also be adequate for conducting dissolution/leach and post-dissolution tests; however, the floor area is not sufficient for conducting the scaled-up experiments.

Before any work in hot cells involving Hanford waste material can be done at ANL, an SAR must be prepared. It is estimated by ANL that this activity requires approximately 5 months.

\subsubsection{Waste Material Disposition}

It is required that all waste generated during Extensive Separations experimentation, together with all residual sample material, be returned to Hanford for disposal. The hot cells are equipped with retention tank drains.

\subsubsection{Analytical Support}

The availability of the needed analytical support for experimentation at ANL is uncertain at this time due to the present priority status of the ongoing programs. 


\subsection{Savannah River Technology Center Resources}

\subsubsection{Hot Cell Availability}

The Chemical Technology Section (CTS) has two hot cells with 12 in. of high-density concrete shielding, 15-in.-thick leaded glass windows, and stainless steel liners. The cells are about $7 \mathrm{ft}$ long, $4 \mathrm{ft}$ deep, and $4 \mathrm{ft}$ high. One cell has been refurbished and is awaiting a funded mission to be restarted. That cell has a 16-stage centrifugal contractor ready to be installed as well as two mixer settlers with four stages each matched to the capacity of the centrifugal contractor. This cell has density instrumentation for in-line measurements. The capability exists for spectrophotometric measurements in the cell. Staff at SRTC estimates about 6 months elapsed time and two full-time equivalent positions to bring the cell into operation.

The SRTC has the ability to receive casks weighing as much as 8 tons. Such large casks are not required for initial small shipments, but could be required for the last part of the program. After receipt, small shipments could be transferred directly to facilities in the CTS. Larger shipments would have to be placed in the large, central hot cells, put in small 250 -mL bottles, and transferred to CTS hot cells in small uranium-shielded containers. The central hot cell facilities are well equipped for homogenization of sludge-type waste samples but not samples containing saltcake. Work in this hot cell would have to be scheduled well in advance of the desired time. The hot cells routinely bring in up to 25-L samples of SRS waste sludge for homogenization and experimentation.

\subsubsection{Waste Material Disposition}

All the hoods, glove boxes, and cells that would be used would have connections to the SRTC high-level waste drain system. The waste is accumulated in a tank and transferred to the SRS waste tank farm for ultimate disposal in glass.

\subsubsection{Analytical Support}

The Analytical Development Section (ADS) of SRTC has up-to-date analytical facilities and equipment that is used to support the SRS high-level waste program. Samples can be transferred to ADS for accurate analysis. Low-level counting facilities are available from another section at SRC if required during the experiments. This section has analyzed samples for I-129 in the past so the procedures are available. All other support services are provided as part of SRTC operations.

The CTS has four to six hoods that could be used for experimentation if the dose rate from the sample is acceptable. It also has two glove boxes in operation and another that could be brought into operation if the radiation can be adequately shielded to minimize dose to personnel. The new glove box requires design and installation of a fire alarm system tied to the building system. This work has already been requested; however, the timing for completion is uncertain. The box can be brought into operation with about 3 man-months of work over 6 months plus the cost of the fire alarm system. 
In a written reply to a PNL inquiry regarding available resources for supporting Extensive Separations experimentation, SRTC stated that they could not commit personnel to unfunded projects, such as Extensive Separations experimentation, but if funding becomes available, manpower will also be available.

\subsection{Los Alamos National Laboratory Resources}

\subsubsection{Hot Cell Availability}

Four hot cells are currently available to support Extensive Separations experimentation. Two additional hot cells will become available the beginning of FY 1994. Samples with radiation readings greater than $300 \mathrm{mR} / \mathrm{h}$ (beta plus alpha at contact) may be received into these hot cells after the hot cells are permitted either through an Unresolved Safety Question determination or a graded SAR. Each hot cell has $36 \mathrm{ft}^{2}$ of floor area and is equipped with one window, two Model AFT manipulators at each window, and a 3-ton bridge crane. Two adjacent hot cells can be combined into one hot cell by lowering a wall separating the cells, thus increasing the floor area to $80 \mathrm{ft}^{2}$. Each hot cell is designed for $100,000 \mathrm{Ci}$. Glove boxes may also be attached to the hot cell line. LANL estimates that 3 to 6 months would be required for installation. Hot cell access is via one door ( $4 \mathrm{ft}$ by $10 \mathrm{ft})$, supplemented by two 10 -in. portals and numerous holes ranging from $0.5 \mathrm{in}$. to 4 in. These hot cells would have adequate floor area to accommodate the dissolution/leach and post-dissolution tests; however, it is doubtful that there is sufficient floor area to accommodate scaled-up testing.

LANL can handle a package (cask plus overpack) weighing up to 25 tons. Each hot cell can accommodate a cask weighing up to 3 tons.

\subsubsection{Waste Material Disposition}

In accordance with existing LANL procedures, LANL will dispose of any wastes generated as a result of analysis. However, if waste volumes exceed 55 gallons per month, LANL may have to consider returning waste to Hanford.

\subsubsection{Analytical Support}

A limited number of samples that are less than $300 \mathrm{mR} / \mathrm{h}$ (beta plus alpha at contact) may be received now directly into the analytical laboratory. Analytical laboratory space, consisting of about three laboratory modules ( $288 \mathrm{ft}^{2}$ each), is available and certain analytical instrumentation is available immediately on a shared basis with other projects. An additional three laboratory modules can be made available within 6 months, depending on the number of samples and required analyses. Each module contains glove boxes, open-front boxes, and fume hoods. Some laboratory modification may be necessary to perform analyses on samples depending on the data quality objectives, number of samples, and types of analyses required. 
The analytical support staff consists of about 100 chemists, technicians, and support personnel performing a wide variety of analytical analyses on radioactive samples containing actinides and transactinides. One radioactive sample of Hanford tank waste has already been analyzed by this organization for elemental and actinide content. LANL's expertise includes inorganic and organic analyses, research and development in process chemistry, and radiochemistry of highly radioactive actinide bearing samples. This analytical expertise is immediately available on a shared basis.

\subsection{Sandia National Laboratory Resources}

The SNL Hot Cell Facility contains three laboratories onsite: the hot cell laboratory, the glove box laboratory, and the analytical support laboratory.

\subsubsection{Hot Cell Availability}

The hot cell laboratory is a concrete-shielded area containing three steel containment boxes and an experiment staging area. Each containment box and the staging area can contain up to $6000 \mathrm{Ci}$ of fission products. The first cell (containment box) contains remotely operated equipment (saws, drill, welding equipment). The second cell contains equipment for metallic and ceramic sample preparation (potting, grinding, and polishing) and for microscopic examination. The third cell is principally used for wet chemistry. Cells 1 and 3 each have $85 \mathrm{ft}^{2}$ of floor area, whereas Cell 2 has $43 \mathrm{ft}^{2}$ of floor area. Cell access is via an 18-in.-diameter pass-through in the ceiling. Cells 2 and 3 are equipped with Model-8 manipulators, whereas Cell 1 has Model-D manipulators. Cells 1 and 3 have two windows, with a manipulator at each window. Cell 2 has one window with a manipulator. Each cell is also equipped with a 0.5 -ton winch and a 0.5 -ton hoist. Radioactive packages are removed from or lowered into the hot cell through the controlled opening (18 in. in diameter) in the ceiling by means of a winch inside a 15-ton shielded transportation cask.

The hot cells are reportedly underused and not currently committed to a project. However, Cells 1 and 2 may not be available to support Extensive Separations experimentation because of currently installed equipment. Since Cell 3 is a wet chemistry cell, it would be immediately available.

The applicability of this hot cell facility to Extensive Separations experimentation is questionable. The floor area of the cells would be sufficient for the dissolution/leach and post-dissolution tests; however, there is not sufficient floor area to accommodate the scaled-up tests. Moreover, the adequacy of the hot cell access and cask-handling capability is also questionable.

The glove box laboratory consists of 10 glove boxes, 6 of which are interconnected. Two of the boxes are shielded and fitted with master-slave manipulators. Up to $300 \mathrm{Ci}$ of fission products can be handled in each of these two boxes. Also located in the glove-box laboratory is a large "walk-in" type fume hood with an 8-ft-wide face opening. 


\subsubsection{Waste Material Disposition}

The provisions for waste disposition at this facility are currently unknown.

\subsubsection{Analytical Support}

The capability for wet chemical analysis at this facility is limited. Moreover, the availability of qualified staff to provide both analytical chemistry support and process chemistry support is unknown. 


\subsection{Technical Requirements}

The primary technical requirements that need to be satisfied to facilitate implementation of Extensive Separations Experimentation and ensure the completion of this work within 5 years are as follows:

- Ensure that an adequate amount of relevant sample material is made available to the program within the time-frame specified in Table 2.2.

- Fabricate a minimum of four shipping containers with a capacity of $10 \mathrm{~L}$ or greater, certify them for Type B liquid transport in accordance with 10 CFR 71, and make them available within 2 years.

- Ensure that adequate analytical support is available to the program both at Hanford and at other selected DOE laboratories.

To ensure that an adequate amount of relevant sample material is obtained within the required time frame, at least 50 tanks containing relevant material (primarily sludge) must be sampled within 33 months, retrieving up to 2 cores per tank to obtain a total of 100 cores. Only 13 of the 50 tanks currently identified to be sampled are defined as having a sludge waste type. Of these 13 tanks, 11 are tanks that will be sampled using an auger, and the sample will consist of only one or two segments. This would not be enough sample material to satisfy the needs of this program, let alone the needs of the tank characterization program. It is therefore required that additional tanks containing relevant material (supernate, saltcake, and sludge) be identified for sampling and that an additional rotary sample rig and crew be dedicated to providing sample material to support this program. In addition, it is required that one of the two hot cell facilities equipped for core extrusion and sample homogenization be dedicated to the support of this program. It is also required that weather barriers be provided to reduce down-time during the sampling operation because of wind and rain.

If other DOE laboratories are required to participate in this program, then the requirement exists to fabricate a minimum of four shipping containers for liquid in accordance with 10 CFR 71 . These units must have sufficient capacity for transporting the quantities of liquid type sample material identified in Table 2.2, must have Type B certification, and must be available to this program within 2 years. SNL is currently working on this requirement.

It is required that analytical support laboratories and laboratory staff at both Hanford and at other DOE laboratories selected to participate in this program be dedicated to this program, and that major equipment procurement be identified and initiated immediately. This requires that adequate funding for this task be made available immediately.

Based on this study, it is concluded that adequate hot cell facilities to support this program are available at Hanford and at other DOE laboratories. 


\subsection{Schedule and Critical Path Impacts}

The experimental work to be conducted (as outlined in Workshop 1) has been scheduled using a critical path method logic-driven network, which is used to identify critical impacts to the completion of the experiments within the 5-year plan. The proposed schedule (Figure 5.1) consists of two major components, the saltcake/supernate experiments and the sludge experiments.

In preparing the schedule, the assumptions made in Section 2.1 of this document were used.

\subsection{Sample Retrieval Schedule Considerations}

- Tank waste retrieval for the different experiments will require up to three samples per month. The two sampling trucks available to take 10 to 15 core samples per year will not be adequate to retrieve core samples to support the schedule. A minimum of one additional sampling truck would be required to meet the experimental needs.

- Two additional transport trucks available for transporting these samples from the tank farms to the 300 Area will also be required to maintain the schedule. Each core sample contains an average of seven segments, which will require two to three round trips per core. For the 36 core samples needed, this would amount to 80 to 100 trips per year. To accommodate the three cores per month that are needed, a total of three transport trucks would be required.

\subsection{Packaging and Transportation Schedule Considerations}

- To ship waste samples to other laboratories, a Type B cask would need to be developed. Based on information supplied from SNL, this cask would take 18 to 24 months to prepare, depending on whether a current cask can be modified to accept Type B waste, or if a new one needs to be designed. A 2-year cask development activity was added to the schedule and until this cask is designed, all testing on Type B waste will have to be conducted at the Hanford Site.

- The estimated 2-year lead time for the availability of a suitable offsite shipping cask for the sample material will adversely impact the schedule. The sludge dissolution/leaching tests to be conducted will require 100 core samples, each requiring three separate tests. To complete the needed test within the given time frame, nine tests per month are required. Currently, Hanford is capable of performing a maximum of three tests per month, because of current laboratory commitments to other work. Hence, until a suitable cask becomes available for offsite transportation, 3 months will be required to conduct the nine tests on each core sample, using currently available laboratory support. This will cause the sludge testing to be completed in May 1999, an 8-month schedule 
impact to the suggested September 1998 completion date. However, if the existing laboratory facilities and laboratory staff in the 325 Building were dedicated to this task, the work could be completed at Hanford within the proposed schedule.

- The saltcake/supernate initial testing is based on three separate tests per sample, and these experiments were assumed to be conducted at three different DOE laboratories. It is estimated that Hanford facilities can perform two tests per month during cask development if additional Hanford laboratory resources, such as those existing in the 325 Building, are dedicated to this effort.

- Upon completion of the cask development, one to three casks will be needed to complete the initial and scaled-up saltcake/supernate testing, and an additional two to three casks will be needed for the sludge experiments. A maximum of six samples are schedule to be tested simultaneously, and the number of casks needed will be dependant on where the tests are going to be performed and how large of a waste sample can be accommodated by the cask.

\subsubsection{Schedule Information}

- Supernate/saltcake simulant testing is scheduled to begin in October 1993. The results from this simulant testing will be used to decide on the three candidate flowsheets that will be used to test actual waste. This information is scheduled to be completed by October 1995 .

- Sample retrieval activities on the schedule indicate the date that the samples need to be taken from the tanks. The time needed to prepare the sampling trucks, complete the necessary administrative work, and other miscellaneous preparations is not scheduled. It is assumed that these activities will be completed in time to meet the proposed schedule requirements.

- A cask needed to ship Type B waste is scheduled to begin design in the beginning of FY 1994 and will be utilized as soon as it is completed. The conservative 2-year development duration was used in the schedule preparation.

\subsection{Schedule Risks}

- Based on the experimental logistic plan, waste retrieval is scheduled to occur up to three times a month over a 4-year period, covering all seasons and conditions. Due to the strict safety requirements on tank waste retrieval, this may be an unrealistic expectation. To help alleviate the potential schedule impact that could be imposed by adverse seasonal conditions, it may be possible to retrieve core samples at a faster rate when conditions allow, thus allowing for less sampling activity at other times. However, in this case, some samples may have to be stored until the experiments can be performed. Currently, the laboratory has ample waste storage capacity available; however, it is required that this space be dedicated for this purpose if this is considered as a viable approach. 
- Currently, only two sampling trucks are operational in the tank farms, and they are scheduled to take samples at a rate of 10 to 15 samples per year. This will not allow for the 36 samples per year that are required to support the schedule. If additional sample trucks or other means of retrieving samples are not identified by early FY 1994, the schedule is at risk of being impacted. Based on the current retrieval capability, the schedule will be impacted by 12 to 18 months.

- Unless a cask suitable for shipping sample material offsite is made available immediately, all experiments will have to be performed at the Hanford Site utilizing currently available laboratory support. This will result in an unavoidable 8-month schedule impact unless additional existing onsite laboratory support is dedicated to this effort, at least during the interim, until a cask becomes available.

- There is a maximum of five to six tests scheduled to be ongoing in a 1-month period at the Hanford Site until Type B casks can be developed. This high work load will have to be closely coordinated with other work at Hanford and may pose a risk if the resources needed to conduct these tests are not available.

\subsection{Schedule Summary}

One critical impact to the proposed schedule is the development of the Type B containment/ transportation cask. Until a cask can be used, all actual tank waste experiments will have to be conducted onsite, which will cause an 8-month schedule impact to the desired 5-year experimental plan. The possible solutions to recover this delay are:

- provide a suitable shipping cask onsite at Hanford by December 6, 1993

- dedicate existing laboratory facilities and laboratory staff in the 325 Building at Hanford or equivalent to support this activity until a suitable shipping cask is provided.

Another critical impact to the logistic schedule is the waste sample retrieval. The logistic plan calls for cores to be taken up to three times per month, while current capabilities indicate that oniy one to two samples per month can be retrieved. If samples cannot be retrieved according to the proposed logistic schedule, a 12- to 18-month impact should be anticipated. 


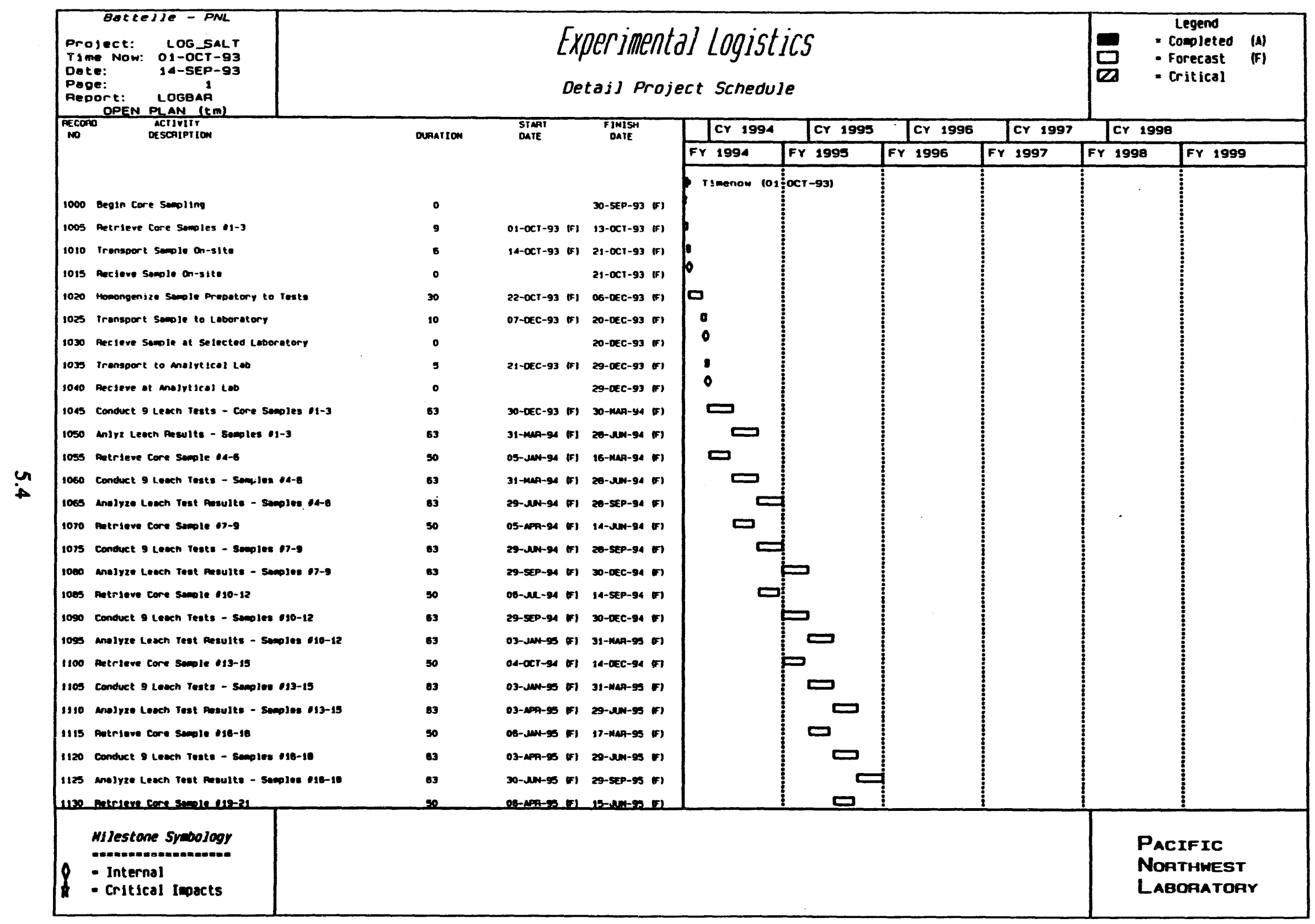

Figure 5.1. Experimental Logistics 


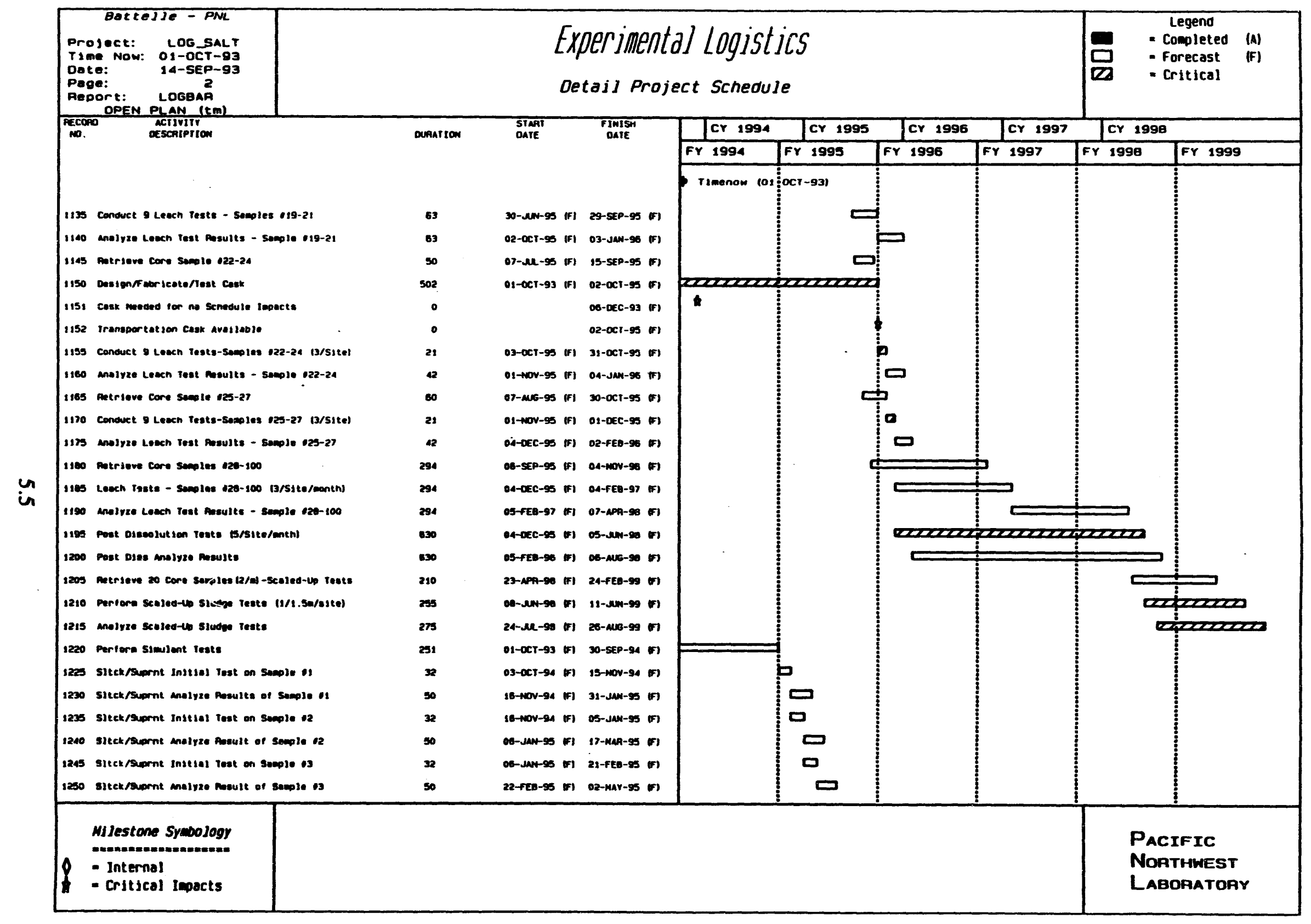

Figure 5.1. (contd) 


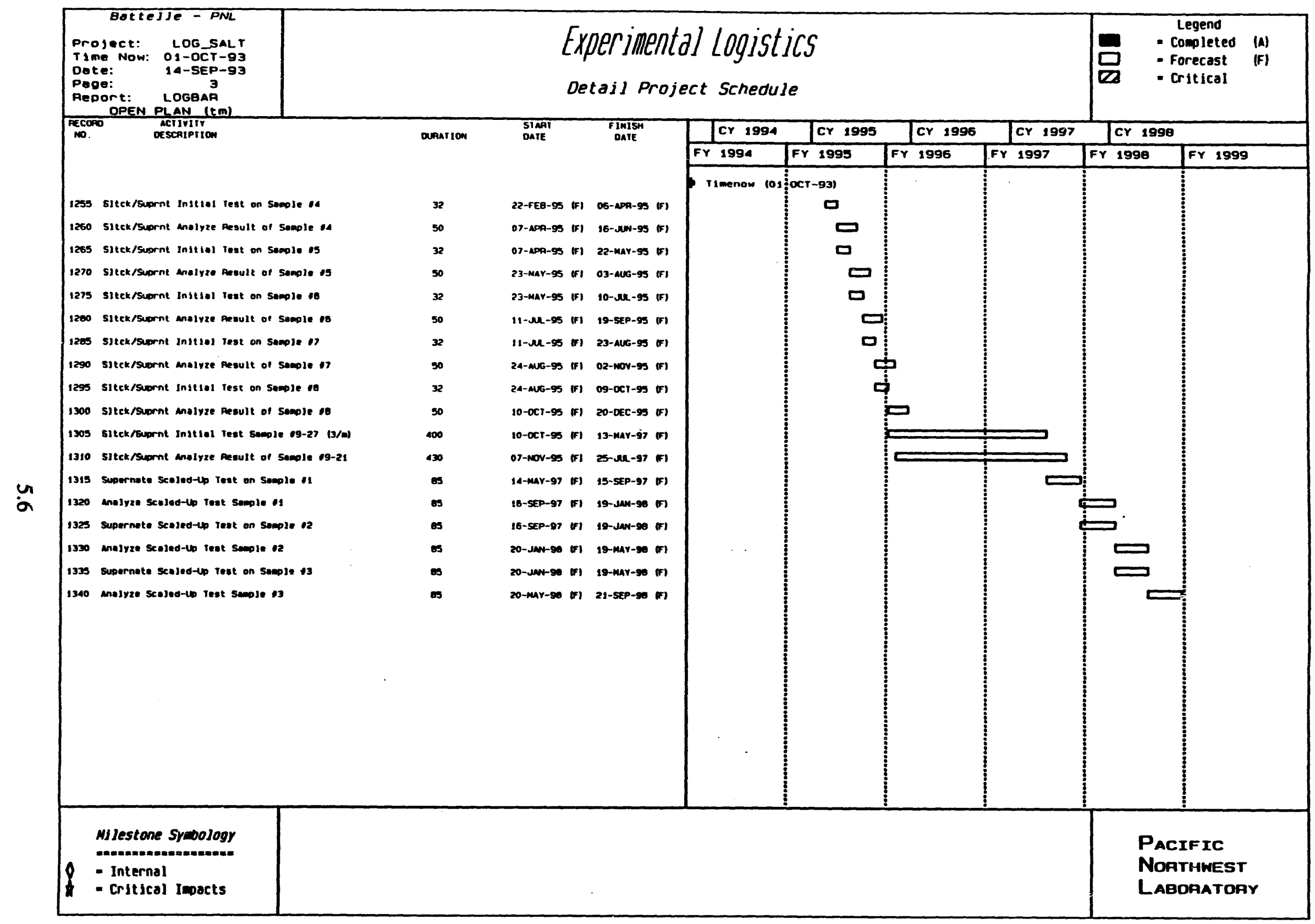

Figure 5.1. (contd) 


\subsection{Reference}

Straalsund, J. L., J. L. Swanson, E. G. Baker, J. J. Holmes, E. O. Jones, and W. L. Kuhn. 1992. Clean Option: An Alternative Strategy for Hanford Tank Waste Remediation. Volume 1, Overview. PNL-8388, Pacific Northwest Laboratory, Richland, Washington. 


\section{Distribution}

No. of

Copies

\section{OFFSITE}

12 DOE/Office of Scientific and Technical Information

J.C Tseng

Trevion 11 Building 12800 Middlebrook Road

Germantown, MD 20874

Argonne National Laboratory CMT Building 205

9700 South Cass Avenue

Argonne, IL 60439-4837

ATTN: J. Hoh

G. S. Vandegrift

Los Alamos National Laboratory P.O. Box 1663

Los Alamos, NM 87545

ATTN: M. Attrep, J514

G. E. Bently, G740

L. R. Field, G730

R. J. Herbst, A145

J. M. Ledbetter, G742

R. Villarreal, G740

Oak Ridge National Laboratory

P.O. Box 2008

Oak Ridge, TN 37831

ATTN: E. D. Collins

A. G. Croff

B. Z. Egan

Sandia National Laboratory

P.O. Box 5800

Albuquerque, NM 87185-5800

ATTN: D. J. Ammerman, 6642

M. E. McAlaster, 6642

A. T. Trennel, 6642

H. R. Yoshimura, 6641
No. of

Copies

Major C. Thompson

Savannah River Technology Center

Building 773A, Room C140

Aiken, SC 29808

\section{ONSITE}

\section{DOE Richland Operations Office}
S. T. Burnum
R3-74

12 Westinghouse Hanford Company

J. N. Appel S4-58

S. A. Barker S4-55

G. E. Culley N1-21

D. R. Doman B5-24

M. L. Grygiel B1-58

H. D. Harmon R2-52

J. G. Hill R2-12

R. A. Karnesky H0-39

W. C. Miller \$4-55

T. W. Oden R2-18

M. J. Wiemers N1-21

P. A. Young R2-14

35 Pacific Northwest Laboratory

C. R. Allen P7-35

W. J. Apley K1-73

G. H. Bryan P7-25

F. G. Buck K8-37

C. D. Carlson P7-25

L. R. Dodd K8-31

W. I. Enderlin (5) K8-41

J. O. Heaberlin K8-14

E. J. Hirschi P7-18

B. M. Johnson K1-78

G. J. Lumetta P7-25

Distr.1 
No. of

Copies
G. B. Mellinger
K1-79
J. M. Seay
P7-38
R. D. Scheele
P7-25
E. A. Schmieman
K8-37
L. J. Sealock
K2-10
B. D. Shipp
K8-28
J. L. Straalsund

No. of

Copies

J. L. Swanson (5) P7-25

J. M. Tingey P7-25

T. W. Wood K8-41

Publishing Coordination

Technical Report Files (5) 

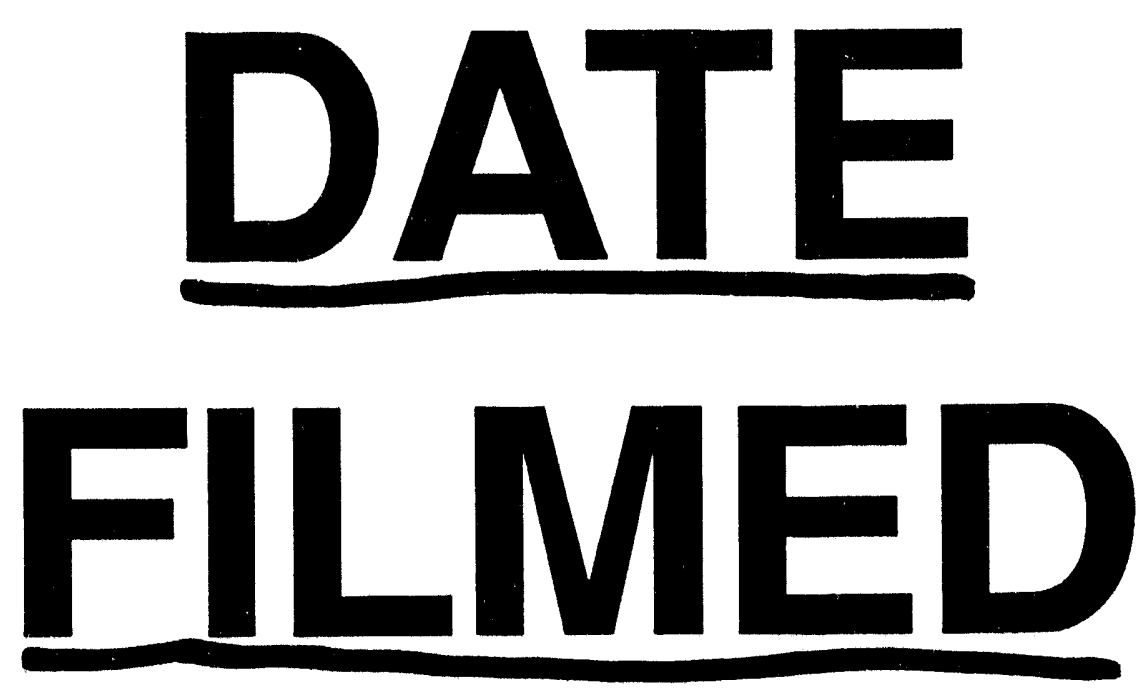

$6 / / 5 / 94$
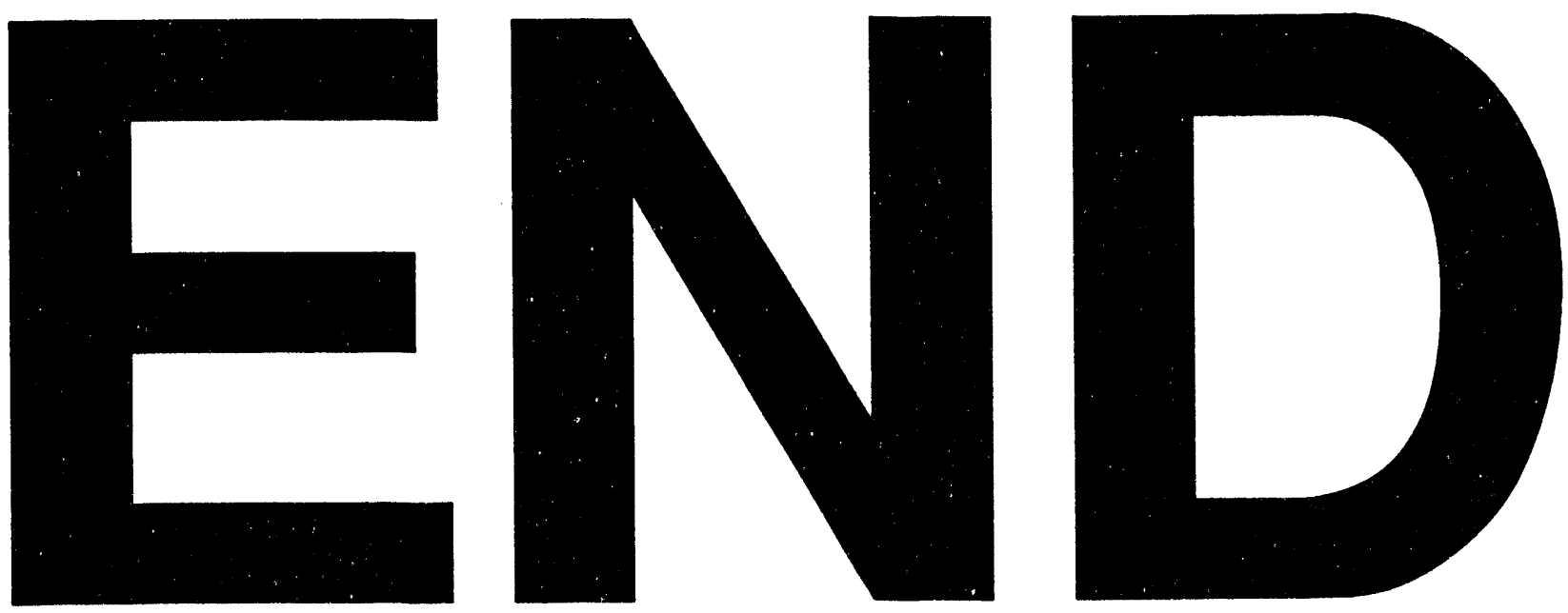

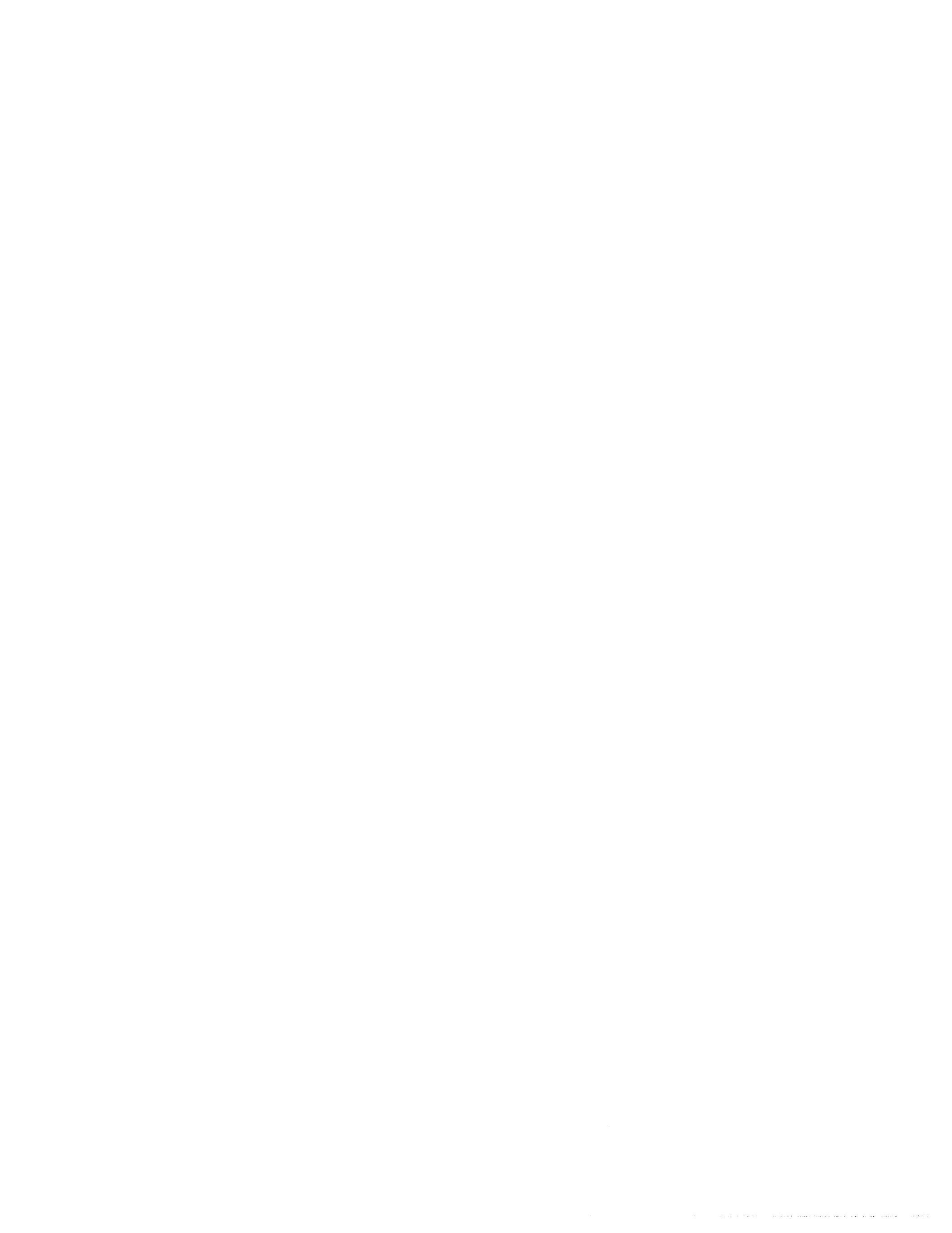